This item was submitted to Loughborough's Research Repository by the author.

Items in Figshare are protected by copyright, with all rights reserved, unless otherwise indicated.

\title{
Effects of driver work-rest patterns, lifestyle and payment incentives on long- haul truck driver sleepiness
}

PLEASE CITE THE PUBLISHED VERSION

https://doi.org/10.1016/j.trf.2018.10.028

PUBLISHER

(C) Elsevier

VERSION

AM (Accepted Manuscript)

\section{PUBLISHER STATEMENT}

This paper was accepted for publication in the journal Transportation Research Part F: Traffic Psychology and Behaviour and the definitive published version is available at https://doi.org/10.1016/j.trf.2018.10.028.

\section{LICENCE}

CC BY-NC-ND 4.0

\section{REPOSITORY RECORD}

Mahajan, Kirti, Nagendra R. Velaga, Akhilesh Kumar, Alok Choudhary, and Pushpa Choudhary. 2019. "Effects of Driver Work-rest Patterns, Lifestyle and Payment Incentives on Long-haul Truck Driver Sleepiness". figshare. https://hdl.handle.net/2134/35759. 


\title{
Effects of driver work-rest patterns, lifestyle and payment incentives on long-haul truck driver sleepiness
}

\author{
Kirti Mahajan ${ }^{1}$, Nagendra R Velaga ${ }^{1}$, Akhilesh Kumar $^{2}$, Alok Choudhary ${ }^{3}$, Pushpa Choudhary ${ }^{1}$ \\ 1 Transportation systems engineering, Department of Civil Engineering, Indian Institute of Technology \\ (IIT) Bombay, Powai, Mumbai-400 076, India \\ 2 Industrial \& Systems Engineering, Indian Institute of Technology (IIT) Kharagpur, Kharagpur \\ India - 721302 \\ ${ }^{3}$ School of Business and Economics, Loughborough University, Leicestershire, LE11 3TU, UK.
}

\begin{abstract}
:
The aim of the study is to identify and model the role of payment incentives, driver work-rest patterns and other lifestyle habits influencing the drowsy driving behavior among long-haul truck drivers. To achieve this aim, this study targeted two main objectives: (1) to examine the significant differences between the groups of drowsy and non-drowsy drivers based on the opportunities of monetary incentives and (2) to examine the role of different factors: driver demographics, work-rest patterns, lifestyle and occupational characteristics particularly incentives associated with driving in causing driver sleepiness among Indian truck drivers. The study is based on interview responses from 453 long-haul truck drivers approached in three Indian cities- Mumbai, Indore and Nagpur.

Initial principal component analysis of the responses related to financial incentives (occupational characteristics) resulted into two correlated factors: (i) willingness to earn extra payments if offered (WEP) and (ii) incentives available in the current driving experience (ICD) that influence driver work-rest patterns and alertness while driving. Kruskal-Wallis test showed a significant difference among the groups of sleepy and non-sleepy drivers due to these factors (WEP and ICD). Finally, a logistic regression model showed that long driving duration, working days per week, rest patterns, insufficient sleeping hours and history of violations were found significantly associated with drowsy driving among the long-haul truck drivers. Increase in consumption of caffeine and tobacco indicated reduction in driver alertness. According to the model results, the odds of drowsy driving were $77 \%$ less for drivers between $46-55$ years compared to the young drivers $(<25$ years). Driving under the influence of financial incentives was observed to increase the odds of falling asleep by 1.58 times among the truck drivers. This was apparently the most interesting and intriguing result of the study indicating the need for further research on the influence of financial or socio-economic motivations to sleepiness.
\end{abstract}

Keywords: Drowsy driving; Driver lifestyle; Driver behavior; Safety; Truck drivers; Driving motivations. 


\section{Introduction}

Indian trucking industry caters to $65 \%$ of total freight transport in India (Asian Institute of Transport Development (AITD), 2015; Raghuram, 2015). With increase in globalization, the demand of road freight transportation is expected to increase further. Truck drivers who form the human backbone of this industry are often involved in long distance trips compromising their rest or sleep requirements. Indian trucks travel at an average speed of $20-40 \mathrm{~km} / \mathrm{h}$ and average distance travelled by Indian truck drivers is about 250-300 kilometers per day which is less than half the daily mileage of the US and UK truck drivers (Medvedev et al., 2014). Poor road and maintenance conditions in India not only reduce the mileage but also add to driver health and safety problems (Asian Institute of Transport Development (AITD), 2000). Indian truck drivers often drive without any adequate rest which might be the cause of their fatigue and higher involvement in accidents (Raghuram, 2015). As stated in the Fatality Analysis Reporting System (FARS) report, 11.2\% of all road crashes during 2015 involved at least one large truck in the US (Highway Traffic Safety Administration \& Department of Transportation, 2015). In a report by Australian Transport Council (2011-2020), 20-30\% of fatalities on the roads are as a result of fatigue and drowsy driving (National Road Safety Strategy, 2011). The situation is more severe in developing countries such as India. The National Crime Record Bureau (NCRB) of India recorded that trucks used for transporting commercial goods accounted for $19.4 \%$ of the total deaths due to road accidents in 2015 (National Crime Records Bureau, 2015). Amongst the total road accident fatalities, $60 \%$ were owed to erroneous driver behavior during overtaking maneuvers, distraction or lack of alertness, etc.

In the context of driver behavior, the terms 'sleepiness', 'drowsiness' and 'fatigue' are used interchangeably in previous studies to denote driver's level of alertness or driver exhibiting any symptoms of falling asleep at the wheel (e.g. Anund, Kecklund, \& Åkerstedt, 2011). Sleepiness or sleep propensity is one's tendency to fall asleep as a result of imbalance or alterations in sleep-wake mechanism (Johns, 2000). Phillips et al., (2017) defined fatigue as "the body-mind response to sleep loss or prolonged physical or mental exertion". In case of truck drivers, long hours of wakefulness, irregular shifts disturb the sleep-wake mechanism resulting in driver sleepiness. However, the conditions like stress and lack of proper sleep among truck drivers may lead to exertion causing fatigue over the long journeys (Phillips, 2015). Fatigue or sleepiness among drivers is marked by various symptoms like frequent blinking, yawning, difficulty remembering the past few miles driven, drifting from one's lane etc. These symptoms are commonly termed as 'lapses' in the standard 'Driver Behavior Questionnaire' (e.g. Bener et al., 2007; Reason et al., 1990). The current study has also used these terms as synonymous to each other. Symptoms of fatigue and drowsiness can cause negative influence on driving (AlHouqani, Eid, \& Abu-Zidan, 2013; Alonso et al., 2016; McCartt et al., 2000). Sleepiness at the wheel increases the odds of accidents (Blower, Green, \& Matteson, 2010; Sullman et al., 2002; Bener et al. 2007). Drowsy driving can lead to severe property damages, injuries and fatalities, but is usually under-reported (Anund et al., 2011; Sagberg, 1999; Tefft, 2012). Many previous studies have focused on drowsy driving problem among truck drivers which suggest driver demographics, lifestyle and work-rest patterns are the main factors that contribute to driver 
alertness (confer Table 1) (Duke et al., 2010; Castillo-Manzano et al., 2016; Teoh et al., 2017; Meng et al., 2015; Kanazawa et al., 2006; Papadakaki et al., 2008; Tzamalouka et al., 2005).

In India, the work-rest periods for drivers of goods carrying heavy vehicles are governed by the 'Hours of Service (HOS)' rules under 'Motor Transport Workers (MTW) Act, 1961'(Ministry of Labour \& Employment, 2008). Given the poor road conditions in India, the maximum permitted hours of driving according to this act is eight hours a day which is relatively less than that in developed nations such as the US or the EU (confer Table 1). The working hours in India are extendable to a maximum of 10-12 hours on special occasions and 48 hours a week or in no case beyond 54 hours a week. The driver shall have a rest period for a minimum of nine hours before a trip on a new working day. The hours of work shall not spread for more than two shifts a day. The details of HOS rules and its enforcement actions in India are compared with the US and the EU in Table 1.

Table 1 'Hours of service' rules for heavy vehicle/ truck drivers in India compared to other developed countries.

\begin{tabular}{|c|c|c|c|}
\hline Hours of service rules & India & $\mathbf{U S}$ & $\mathbf{E U}$ \\
\hline Reference & $\begin{array}{l}\text { Ministry of Labour \& } \\
\text { Employment, } 2008\end{array}$ & $\begin{array}{l}\text { Federal Motor Carrier } \\
\text { Safety Administration, } \\
2015\end{array}$ & $\begin{array}{l}\text { Road Safety Authority, } \\
2006\end{array}$ \\
\hline Max. driving hours & 8 hours/ day & 11 hours/ day & 9 hours/ day \\
\hline $\begin{array}{l}\text { Extendable driving hours } \\
\text { * on 'special occasions' }\end{array}$ & $\begin{array}{l}10 \text { hours out of maximum } \\
12 \text { hours on duty }\end{array}$ & $\begin{array}{l}13 \text { hours out of maximum } \\
14 \text { hours on duty }\end{array}$ & $\begin{array}{l}10 \text { hours (maximum twice } \\
\text { a week) }\end{array}$ \\
\hline $\begin{array}{l}\text { Maximum weekly driving } \\
\text { hours }\end{array}$ & 54 hours/week & $\begin{array}{l}60 \text { hours } / 7 \text { days or } 70 \\
\text { hours } / 8 \text { days }\end{array}$ & $\begin{array}{l}56 \text { hours/week } \\
90 \text { hours/fortnight }\end{array}$ \\
\hline $\begin{array}{l}\text { Minimum Rest Time } \\
\text { (Continuous sleep time) }\end{array}$ & $\begin{array}{l}\text { 9-hours/ day and 1- } \\
\text { day/week. }\end{array}$ & 8 to10 hours/ day. & $\begin{array}{l}9 \text { to } 11 \text { hours/day } \\
45 \text { hours/ week }\end{array}$ \\
\hline In-between Breaks & $\begin{array}{l}30 \text { minute every } 5 \text { hours of } \\
\text { consecutive driving }\end{array}$ & $\begin{array}{l}\text { Minimum } 30 \text { minute in } 8 \\
\text { hours of consecutive } \\
\text { driving }\end{array}$ & $\begin{array}{l}45 \text { minute break (or two } \\
\text { breaks of } 15+30 \text { minutes) } \\
\text { every } 4.5 \text { hours. }\end{array}$ \\
\hline Enforcement regulation* & Logbook record & $\begin{array}{l}\text { Logbook/ Electronic } \\
\text { logging device (ELD): } \\
\text { record over last } 8 \text { days. }\end{array}$ & $\begin{array}{l}\text { Tachometer record sheets } \\
\text { over last } 28 \text { days. }\end{array}$ \\
\hline Penalty for violation & $\begin{array}{l}\text { Imprisonment ( } 3 \text { months) } \\
\text { and/ or fine }\end{array}$ & $\begin{array}{l}\text { Suspension from service } \\
\text { and/or fine }\end{array}$ & $\begin{array}{l}\text { Suspension from service } \\
\text { and/or fine }\end{array}$ \\
\hline
\end{tabular}

The enforcement actions in India are neither very stringent (British Columbia Truckers Association (BCTA), 2013; Urie, Velaga, \& Maji, 2016) nor specific for example the number of days for which the logbook record has to be maintained is not fixed as compared to other countries (Table 1). Further, the MTW Act which governs the HOS rules in India is applicable only when the undertaking employs five persons or more (Asian Institute of Transport Development (AITD), 2015; Government of India \& Ministry of Labour and Employment, 1988). The Indian trucking industry is dominated by small truck owners, $75-80 \%$ own less than five trucks (Asian Institute of Transport Development (AITD), 2015; Indian Institute of Management Calcutta, 2009; Medvedev et al., 2014; Raghuram, 2015). It is assumed that the poor economic conditions of Indian truck drivers may also motivate them to falsify their 
logbooks or work more hours to earn extra monetary benefits (British Columbia Truckers Association (BCTA), 2013). Therefore, despite these regulations, violation of work-rest period regulations can be expected in India leading to sleep deprived and fatigued driving. However, it is evident from the literature that very few studies on driver fatigue and drowsiness while driving have been conducted in the developing countries like India.

Some previous studies have found economic factors such as payment based on trip length or monthly flat rate as factors influencing fatigue, but, no such association has been detected with driver sleepiness (Thompson and Stevenson, 2014; Thompson et al., 2015). This study targets to evaluate the influence of additional economic motivations such as productivity-based incentives (e.g. early or on-time deliveries) that may motivate the truck drivers to work for long hours, compromising their need for adequate rest and sleep. Therefore, the aim of this study is to evaluate the role of driver lifestyle and other economic factors on the probability of driver sleepiness at the wheel. To achieve this aim, this study has two main objectives: (1) to examine if there is a significant difference between group of drivers falling asleep while driving and other drivers based on opportunities for monetary incentives and (2) to examine the role of incentives associated with driving and influence of other work and lifestyle factors on driver sleepiness.

\section{Previous Research}

There are two approaches used in the literature to study the drowsy driving behavior among long-haul truck drivers: (1) Naturalistic driving studies and (2) Questionnaire-based surveys. Naturalistic driving studies have been adopted by very few researchers in the past (Chen et al., 2016; Sparrow et al., 2016; Blanco et al., 2011). Whereas, questionnaire-based surveys or analyzing past crash records have been popularly used by the researchers, because these are safer data collection methods and cover a larger population sample (Sullman et al., 2002; Pérez-Chada et al., 2005; McCartt et al., 2000; Kanazawa et al., 2006).

Various analysis techniques have been used by the researchers to study the effects of different lifestyle and sleep-related factors on the probability of drowsy driving and associated crash risk. For instance, Girotto et al. (2016) and Sadeghniiat-haghighi et al. (2016) used multinomial logistic regression and Häkkänen and Summala (2001), Meng et al. (2015), Papadakaki et al. (2008) and Tzamalouka et al. (2005) used logistic regression. Chi-square test (Meng et al., 2015; Williamson \& Friswell, 2013), Kruskal-Wallis test (Philip et al., 2002; Sabahiah et al., 2017), Spearmen correlation (Philip et al., 2002), factor analysis (McCartt et al., 2000; Sullman et al., 2002; Tsao, Chang, \& Ma, 2017), multivariate analysis of covariance (MANCOVA) (Thompson $\&$ Stevenson, 2014) and Agent-Based Modeling (ABM) (Thompson et al., 2015) are also some of the commonly used analysis techniques.

In contrast to India, the previous studies across the globe have elucidated the dimensions of drowsiness problem among commercial or Heavy Vehicle (HV) drivers to some extent (Duke et al., 2010; Castillo-Manzano et al., 2016; Teoh et al., 2017; Meng et al., 2015; Kanazawa et al., 2006). Based on the literature, the major contributing factors to drowsiness problem among drivers are discussed in the following sub-sections. Relevant hypotheses drawn from the 
previous research findings are proposed to be examined in context of Indian truck drivers in the current study.

\subsection{Driver demographics}

Younger and less experienced drivers are generally associated with higher risk of drowsy driving (Barr et al., 2005; Häkkänen \& Summala, 2001; Smith et al., 2009). According to Duke et al. (2010), the drowsiness symptoms were minimum among the middle-aged drivers compared to the young and elderly drivers. The association of driver education level with his alertness or fatigue has been a topic of ambiguity. A higher level of education among licensed drivers are associated with increased mental fatigue and hence increased frequency of drowsy driving (McCartt et al., 1996; Newnam, Mamo, \& Tulu, 2014; Di Milia et al., 2011). On the contrary, Di Milia et al., (2011) and Watt et al., (2000) found that the less/uneducated groups exhibit greater physical fatigue and hence higher risk of drowsy driving. Zhang et al. (2016) found that the education level of truck drivers did not contribute to their risky driving behavior. Driver education may help them understand the risks involved with overtime and inappropriate rest schedules, thus leading to the following hypothesis.

Hypothesis 1: In case of truck drivers, higher education level may reduce driver involvement in drowsy driving.

Married couples tend to share the domestic burden, thus marriage may lessen the consequent mental and physical fatigue on drivers (Di Milia et al., 2011). However, it seems likely that the poor economic conditions, low literacy and unemployment may burden the drivers in India with financial responsibility of their family members. In order to meet the financial needs of dependents/family Indian drivers might prefer to compromise their resting time for extended work hours for incentives. Thus, in context of India, family responsibility is a more appropriate variable than marital status to influence driver alertness. Therefore, the following hypothesis is proposed.

Hypothesis 2: Family responsibility may lead to long working hours and greater exposure to drowsy driving risks.

\subsection{Driver lifestyle and drowsiness}

\subsubsection{Work-rest schedule}

The long working hours and inadequate sleep have been identified as the main reasons for sleepiness while driving among freight vehicle drivers (Papadakaki et al., 2008; Tzamalouka et al., 2005; McCartt et al., 2000; Sadeghniiat-haghighi, Yazdi, \& Mohammad, 2016). Therefore, an adequate sleep of minimum seven hours $(7 \mathrm{~h})$ a day is recommended for safer driving practices (Wheaton et al., 2013; Johnson et al., 2015). Long sleepers ( $>10 \mathrm{~h})$ as well as insufficiently sleeping drivers $(\leq 6 \mathrm{~h})$ show an increased risk of drowsy driving (Maia et al., 2013). Chen et al. (2016) studied the sleep patterns among a group of commercial drivers and found that high fatigue and drowsiness were associated with lack of sleep specifically between 1 am to 5 am. The rotating shift workers are involved in driving and other activities during this period. Thus, the shift workers are expected to be at a greater risk of accidents due to drowsiness compared to 
regular workers (Johnson et al., 2015). Morning rush hours, post-lunch or post mid-night periods are certain safety-critical timings, which are associated with low circadian rhythms and high decrement in alertness while driving (Zhang et al., 2014; Matthews et al., 2012; Aidman et al., 2015; Zhang et al., 2016). The accident risk increases as the duration of driving increases, especially beyond 4 hours of continuous driving (Lin et al., 1984). As stated by the HOS rules in India, it is mandatory for the drivers to take adequate rest breaks while driving and also before starting the shift (confer Table 1). Involvement of drivers in non-driving activities such as loading-unloading or waiting in queues during the work period can increase driver fatigue (Williamson \& Friswell, 2013). Based on the influences of work-rest schedules on driver alertness, the following hypothesis is examined in the current study.

Hypothesis 3: The violations of HOS rules for heavy vehicle drivers and increase in duration of driving could be an important reason for drowsy driving among Indian truck drivers.

\subsubsection{Other lifestyle habits}

Lifestyle habits of freight vehicle drivers have significant effects on their subsequent alertness. Smoking and caffeine consumption are known to be popular measures adopted by the drivers to maintain adequate alertness while driving (Åkerstedt et al., 2002; Tzamalouka et al., 2005; Cantor et al., 2010; Pérez-Chada et al., 2005). The need for consuming caffeinated beverages to stay alert increases with driver drowsiness and fatigue while on duty (Watling et al. 2014; Howard et al. 2014; Johnson et al. 2015). Habit of alcohol consumption negatively influences the driver's sleep quality and quantity leading to problems such as excessive daytime sleepiness and fatigue while driving (Brower, 2009; Ronen et al., 2010). Avoiding alcohol even the night before the drive is considered as a good precaution to avoid risks of drowsy/fatigued driving (Nordbakke \& Sagberg, 2007). Exercise and physical activities are believed to improve the quality of sleep (Chen et al., 2016; McCartt et al., 2000). Adequate consumption of water is also believed to help the driver stay alert (Nordbakke \& Sagberg, 2007; McKernon 2009; Pylkkönen et al. 2015). However, the professional long-haul HV drivers may rarely find time to do anything more than maintaining an active posture on the driving seat and staying hydrated throughout the journey to remain alert and active. Therefore, the following hypothesis is proposed.

Hypothesis 4: Increased need for consumption of caffeinated beverages, alcohol or smoking may indicate the risks of drowsy driving among drivers and sufficient water intake and physical exercise are expected to have a positive influence on driver alertness.

\subsection{Incentives and work-rest pattern}

According to the World Health Organization (WHO) report, people from poor socioeconomic background are more likely to be involved in road-accidents (World Health Organization, 2013). In a developing country like India, the economic incentive or monetary benefits can also influence the driving hours and related safety of drivers. The economic factors such as payment based on the length or duration of the trip influence the safe driving behavior of commercial vehicle drivers (Thompson and Stevenson, 2014; Thompson et al., 2015; Williamson and Friswell, 2013; Campos Monteiro et al., 2015). The work duration can be inclusive of driving and non-driving tasks such as waiting in queues and other subsidiary works like 
loading/unloading activities, upkeep, and maintenance of the vehicle. Williamson and Friswell (2013) and Tzamalouka et al. (2005) found that payment incentives for non-driving duties (for example, waiting idly in queues during the working hours) have been significantly associated with higher fatigue levels among commercial HV drivers. Drivers tend to compromise their rest breaks to meet the arrival time windows (Morrow \& Crum, 2004; Williamson \& Friswell, 2013)(A. Williamson \& Friswell, 2013)[45](A. Williamson and Friswell 2013), incentivizing the arrival windows may put an additional pressure on drivers to drive for long hours. Due to such work pressure, drivers may have poor sleep quality which results in increased speeding offences (Tseng et al., 2016). The drivers tend to adopt shorter routes over an original route or reroute to traffic disturbances with the intention of saving fuel and time (Ericsson, Larsson, \& BrundellFreij, 2006; Dogan, Steg, \& Delhomme, 2011). The intention of saving fuel is also associated with saving money (Lauper et al., 2015). However, preferring the shorter uncomfortable routes to save time and fuel may cause additional fatigue among drivers given the poor road conditions in India (Raghuram, 2015). Therefore, providing opportunities that offer additional payment incentives or monetary benefits to drivers for working by compromising their rest needs encourage the situations of sleepy and fatigued driving. Such economic factors might be responsible for high variants of the level of fatigue and drowsiness experienced by the HV drivers, but, have received limited attention in the previous research. Therefore, the following hypothesis is proposed to be examined in this study.

Hypothesis 5: Accepting opportunities for earning incentives can increase the risks of drowsy driving among truck drivers. 
Table 2 Factors influencing the risks of driver drowsiness/fatigue

\begin{tabular}{|c|c|c|c|}
\hline S. No. & Factor/variable & Studied By & Results from Previous findings \\
\hline & \multicolumn{3}{|l|}{ Dependent Variable } \\
\hline & \multicolumn{2}{|c|}{ Self-reported instances of falling asleep or feeling drowsy at the wheel } & Associated with crash risk due to drowsy driving \\
\hline & \multicolumn{3}{|l|}{ Demographic factors } \\
\hline 1. & Age & $\begin{array}{l}\text { Barr et al., 2005; Häkkänen \& Summala, 2001; Duke et } \\
\text { al., 2010; Otmani, Roge, \& Muzet, } 2005\end{array}$ & Risk of drowsy driving shows a u-shaped curve with age. \\
\hline 2. & $\begin{array}{l}\text { Highest education level } \\
\text { completed }\end{array}$ & $\begin{array}{l}\text { - Di Milia et al., 2011; McCartt et al., 1996; Newnam, } \\
\text { Mamo, \& Tulu, 2014 } \\
\text { - Di Milia et al., 2011; Barr et al., 2005; Sullman et al., } \\
\text { 2002; Watt et al., } 2000 \\
\text { - Zhang et al., 2016 }\end{array}$ & $\begin{array}{l}\text { - Higher educated groups experience greater mental fatigue } \\
\text { - Uneducated/ less educated groups exhibit greater physical } \\
\text { fatigue. } \\
\text { - Insignificant in predicting driver sleepiness at the wheel. }\end{array}$ \\
\hline 3. & Family/Marital status & Di Milia et al., 2011 & Marriage/Spouse may lessen the fatigue of drivers \\
\hline 4. & Driving experience (in years) & Girotto et al., 2016; Sagberg, 1999 & $\begin{array}{l}\text { Low experience is associated with higher risk of crashes due } \\
\text { to drowsy driving. }\end{array}$ \\
\hline \multirow[t]{2}{*}{5.} & Body mass index (BMI) & $\begin{array}{l}\text { - Mills et al., 2008; } \\
\text { - Di Milia et al., 2011; Chen et al., } 2016\end{array}$ & $\begin{array}{l}\text { - Higher BMI increases fatigue. } \\
\text { - Increased BMI is associated with increased risk of crashes }\end{array}$ \\
\hline & \multicolumn{3}{|l|}{ Work-rest pattern } \\
\hline 6. & Duration of work & $\begin{array}{l}\text { Papadakaki et al., 2008; Tzamalouka et al., 2005; } \\
\text { McCartt et al., 2000; Sadeghniiat-haghighi, Yazdi, \& } \\
\text { Mohammad, 2016; Di Milia et al., 2011; Meng et al., } \\
\text { 2015; Häkkänen and Summala, 2001 }\end{array}$ & $\begin{array}{l}\text { Long and hectic work schedules increase the odds of driver } \\
\text { drowsiness }\end{array}$ \\
\hline 7. & Type of work-shift & $\begin{array}{l}\text { Adams-guppy \& Guppy, 2003; Sadeghniiat-haghighi, } \\
\text { Yazdi, \& Mohammad, 2016; Johnson et al., } 2015\end{array}$ & $\begin{array}{l}\text { Night shift and rotating shifts increased the risks of drowsy } \\
\text { driving behavior }\end{array}$ \\
\hline 8. & Driving time of day & $\begin{array}{l}\text { Zhang et al., 2014; Matthews et al., 2012; Aidman et al., } \\
\text { 2015; Chen et al., 2016; Häkkänen and Summala, 2001; } \\
\text { Williamson \& Friswell, } 2011\end{array}$ & $\begin{array}{l}\text { Most tiring time of day for drivers: Post lunch, after } \\
\text { midnight (1am-5am) }\end{array}$ \\
\hline 9. & Intermediate breaks & $\begin{array}{l}\text { - Williamson, Feyer, \& Friswell, 1996; Lin et al., 1984; } \\
\text { - Thompson, Newnam, \& Stevenson, } 2015\end{array}$ & $\begin{array}{l}\text { - More frequent breaks indicate more tiredness among } \\
\text { drivers } \\
\text { - Each hour of driving without breaks over } 4 \mathrm{~h} \text { adds to } \\
\text { fatigue related crash risk }\end{array}$ \\
\hline 10. & Duration of sleep & Maia et al., 2013; Wheaton et al., 2013; Johnson et al., & Short sleep $(<7 \mathrm{~h})$ increases the odds of driver drowsiness \\
\hline
\end{tabular}




\begin{tabular}{|c|c|c|c|}
\hline S. No. & Factor/variable & Studied By & Results from Previous findings \\
\hline & & 2015; Chen et al., 2016 & \\
\hline \multirow[t]{2}{*}{11.} & Non-driving work period & Blanco et al., 2011; Williamson \& Friswell, 2013 & $\begin{array}{l}\text { Additional non-driving activities during work period can } \\
\text { increase tiredness among truck drivers. }\end{array}$ \\
\hline & \multicolumn{3}{|l|}{ Other Lifestyle factors } \\
\hline 12. & Caffeine/ tea intake per day & $\begin{array}{l}\text { Watling et al. 2014; Howard et al. 2014; Johnson et al. } \\
\text { 2015; Philip et al., } 2002\end{array}$ & $\begin{array}{l}\text { Consumption of caffeinated beverages increases with driver } \\
\text { drowsiness and fatigue }\end{array}$ \\
\hline 13. & Physical exercise or activities & Chen et al., 2016; McCartt et al., 2000 & $\begin{array}{l}\text { Physical activities are believed to improve the quality of } \\
\text { sleep }\end{array}$ \\
\hline 14. & Alcohol consumption & $\begin{array}{l}\text { Brower, 2009; Ronen et al., 2010; Nordbakke \& Sagberg, } \\
2007\end{array}$ & Leads to poor sleep quality and easily prone to fatigue. \\
\hline 15. & Smoking/tobacco intake & $\begin{array}{l}\text { Åkerstedt et al., 2002; Tzamalouka et al., 2005; Cantor et } \\
\text { al., } 2010\end{array}$ & Smoking is adopted to increase alertness \\
\hline \multirow[t]{2}{*}{16.} & Water intake while driving & $\begin{array}{l}\text { Nordbakke \& Sagberg, 2007; McKernon 2008; } \\
\text { Pylkkönen et al. } 2015\end{array}$ & Appropriate water intake helps to increase driver alertness. \\
\hline & \multicolumn{3}{|l|}{ Payment related factors } \\
\hline 17. & $\begin{array}{l}\text { Payment type: trip based (by } \\
\text { kms or by output) or time based }\end{array}$ & $\begin{array}{l}\text { Williamson \& Friswell, 2013; Thompson et al., 2015; } \\
\text { Thompson \& Stevenson, } 2014\end{array}$ & $\begin{array}{l}\text { Drivers 'paid by trip' did longer hours of work had less } \\
\text { sleep and were more likely to experience fatigue. }\end{array}$ \\
\hline 18. & Overtime and longer trips & $\begin{array}{l}\text { Åkerstedt et al., 2002; Di Milia et al., 2011; Sadeghniiat- } \\
\text { haghighi et al., 2016; Campos Monteiro et al., } 2015\end{array}$ & $\begin{array}{l}\text { Incentives for overtime encourage extended hours of work } \\
\text { and increased driver fatigue }\end{array}$ \\
\hline 19. & $\begin{array}{l}\text { Economic incentives for non- } \\
\text { driving works }\end{array}$ & Blanco et al., 2011; Williamson \& Friswell, 2013 & $\begin{array}{l}\text { Remuneration for non-driving activities encourage longer } \\
\text { hours of work and driver fatigue } \\
\text { Drivers paid for waiting in queues engaged in lengthy trips }\end{array}$ \\
\hline 20. & Incentives and arrival windows & Williamson \& Friswell, 2013; Morrow \& Crum, 2004 & Arrival time pressures during the trip \\
\hline 21. & $\begin{array}{lcc}\text { Economic } \quad \begin{array}{l}\text { incentives for } \\
\text { overtime \& lengthy trips }\end{array} & \\
\end{array}$ & Arnold et al., 1997; Tsao, Chang, \& Ma, 2017 & $\begin{array}{l}\text { Economic rewards for overtime increase the odds of driver } \\
\text { fatigue }\end{array}$ \\
\hline 22. & Driving actions and saving fuel & $\begin{array}{l}\text { Ericsson, Larsson, \& Brundell-Freij, 2006; Dogan, Steg, } \\
\text { \& Delhomme, 2011; Lauper et al., } 2015\end{array}$ & $\begin{array}{l}\text { Motives of saving fuel influences the driving actions such as } \\
\text { rerouting to shorter routes or traffic disturbances. }\end{array}$ \\
\hline 23. & Speeding & Tseng et al., 2016 & $\begin{array}{l}\text { Overtime leads to fatigue and poor sleep quality which can } \\
\text { cause speeding offences }\end{array}$ \\
\hline
\end{tabular}




\section{Material and Methods}

\subsection{Data collection}

The data was collected using a questionnaire survey. The survey was pilot tested with 20 truck drivers before the actual survey to check its language comprehensiveness. Hence, necessary modifications were made in the final questionnaire. The actual survey was conducted with 490 long-haul truck drivers through face-to-face interviews on routes connecting to three Indian cities (Mumbai, Nagpur, and Indore). The drivers who did not have valid driving license or provided incomplete responses to dependent variable (did not respond to instances of falling asleep while driving) and invalid responses to certain significant questions (e.g., a driver reporting 14 hours of driving on-duty out of self-reported work duration of only 12 hours in a day) were rejected. Therefore, only 453 samples which contained complete and valid responses were included in the analysis.

\subsection{Procedure}

The survey was conducted between March and May 2017. The participation in the survey was entirely voluntary and non-compensated. The surveyors approached the truck drivers for interviews at some specific locations on major freight routes in the outer locations of the cities (highway eateries, rest locations, destinations, etc.). The surveyors began the survey after confirming the willingness of the drivers to spare approximately 30 minutes for the interview. The drivers were then briefed about the aim of the survey. The survey was continued with them if they were long-haul drivers (driving a minimum of $200 \mathrm{kms}$ per day).

\subsection{Questionnaire description}

The questionnaire used in this survey consisted of measurements for driver demographics, workrest pattern, other lifestyle factors, payment characteristics and safety-critical events due to driver drowsiness. Some sections such as identification of drowsy lapses were adopted with minor modifications from the Driver Behavior Questionnaire (DBQ) used in previous studies (Reason et al., 1990; Sullman et al., 2002; Williamson and Friswell, 2013 etc.). Based on the literature (Table 2), the detailed questionnaire was divided into the following sections to collect information about the independent variables in the study:

a) Driver demographics: It contained details like age, experience (years of holding a professional truck driving license), education, family responsibility, and body mass index (BMI) in $\mathrm{kg} / \mathrm{m}^{2}$.

b) Work-rest pattern: This section included information about driver's work-rest pattern such as the duration of work (driving and non-driving activities such as loading, unloading, waiting idly in queues at the loading-unloading sites, etc.), driving and sleeping per day, interval as well as the purpose of breaks within the driving schedule, type of work shift (fixed or rotating shifts), day-time or night-time driving. 
c) Other lifestyle habits: This section consisted of driver responses about the consumption of tobacco/cigarettes, intake of alcohol, caffeine/tea beverages and water consumed every day while driving or on-duty to stay alert.

d) Payment incentives: Based on the literature in Table 2, additional questions were designed to identify the role of payment incentives (refer Appendix-1). The questions were provided with different situations related to payment and its influence on driver working hours and driver actions. The situations indicating either the likeliness or current practice of availing opportunities to earn incentives at the cost of ignoring rest requirements were asked. For example, the questions included: "Will you prefer to take night shift (8pm-8am) over day shift for any additional payment?", "Do you receive any financial reward for early or on time arrivals?"

e) Safety-critical events (SCES): This section included information about experiences of drowsy driving and safety related events. The drivers were asked about their history of drowsy lapses while driving ("how often have you felt drowsy with symptoms such as frequent yawning, or no clear recollection of the road you just travelled or difficult to concentrate due to sleep?", "have you ever fallen asleep while driving the heavy vehicle in the past five years?"). They were also asked about the effect of such lapses on their driving (ran off the road, nothing happened, etc. confer Figure 1) and their history of atfault accidents due to fatigue or drowsiness in the last five years (i.e., have you been involved in any at-fault accident/ near miss crash due to drowsy driving).

\subsection{Descriptive statistics}

The details of drivers and their lifestyle characteristics are presented in Table 3 and Table 4. Most of the drivers in the current sample belong to the age groups $26-35$ years $(47.9 \%)$ and 3645 years $(30.9 \%)$ and therefore, corresponding ranges of experience of 5-10 years $(42 \%)$ and 10 15 years $(26.7 \%)$ were identified. $14.3 \%$ were novice drivers having experience below five years. It is mandatory for the truck drivers to have a minimum qualification of 'eighth standard' to acquire the license for driving a commercial vehicle (Central Motor Vehicles Rules, 1989); however, the sample shows $19.4 \%$ cases of its violation. In India, the system of joint families still prevails and therefore, sometimes high financial responsibilities fall on few working people in the family. The average household size in India is 4.9 which is almost double the average household size (2.1-2.5) in majority of western developed nations (Department of Economic and Social Affairs, 2017). In the current sample, around $85 \%$ of drivers reported that either they have family responsibility or they are the sole earners in the family. Also, $81 \%$ of the drivers were married in the current sample.

Drivers reported driving for an average of 9 hours $(\mathrm{SD}=2.26)$ out of average $13.6(\mathrm{SD}=5.35)$ hours of on-duty daily for almost all seven days a week (confer Table 3). However, in actual practice, they might take up long continuous drives within a week and then rest for consecutive 2-3 days, which makes the actual hours of driving more than 9 hours on a working day. Most drivers worked in irregular shifts (64\%). Around 36\% drove during day-time (8:00 am-lunch) and $23 \%$ during night time (8:00 pm to 1:00 am). Most of the drivers took breaks only for taking meals $(42 \%)$ and very few for rest (3\%) while driving. $36 \%$ of drivers reported that they sleep 
only up to 6 hours every day; and merely $43 \%$ reported taking an adequate sleep of 6-8 hours. Around $40 \%$ drivers believed that the rest time they get is insufficient to alleviate their fatigue. $77 \%$ drivers received a flat rate fixed monthly salary and remaining based on either trip length or on the delivery of products. Mean BMI of drivers was $23.26(\mathrm{SD}=4.47)$ and mostly did not engage in any physical exercise in their routine. 17\% reported drinking alcohol, $46 \%$ reported smoking or intake of tobacco daily and $75 \%$ consumed caffeinated drinks minimum three times a day to alleviate fatigue during driving, while only $35 \%$ preferred consuming sufficient water (minimum of 2 liters per day) which helps to remain alert.

Table 3 Descriptive Statistics of duration of on-duty period.

\begin{tabular}{|l|c|c|c|c|c|}
\hline Variable description & N & Minimum & Maximum & Mean & $\begin{array}{c}\text { Std. } \\
\text { Deviation }\end{array}$ \\
\hline On duty working hours/day in last 5 years (in hours) & 453 & 5 & 24 & 13.62 & 5.35 \\
\hline Duration of driving per day (in hours) & 453 & 4 & 16 & 8.54 & 2.26 \\
\hline Number of working days in a week & 453 & 2 & 7 & 6.42 & 0.95 \\
\hline
\end{tabular}

Table 4 Descriptive statistics of categorical variables

\begin{tabular}{|c|c|c|c|c|}
\hline Description & $\begin{array}{c}\text { Variable } \\
\text { Coding }\end{array}$ & Categories & $\begin{array}{c}\text { Frequency/ } \\
\text { number }\end{array}$ & $\begin{array}{l}\text { Percent } \\
(\%)\end{array}$ \\
\hline \multirow{5}{*}{ Age } & Age & 25 or below & 49 & 10.82 \\
\hline & & $26-35$ & 217 & 47.90 \\
\hline & & $36-45$ & 140 & 30.91 \\
\hline & & $46-55$ & 39 & 8.61 \\
\hline & & $56+$ & 8 & 1.77 \\
\hline \multirow{4}{*}{ Education } & edu & (School level) Grade 5 & 88 & 19.43 \\
\hline & & (School level) up to Grade 8 & 202 & 44.59 \\
\hline & & Metric or 10th grade & 92 & 20.31 \\
\hline & & (Pre-college level) 12th & 71 & 15.67 \\
\hline \multirow{2}{*}{$\begin{array}{l}\text { Family responsibility/ } \\
\text { Sole earners }\end{array}$} & famresp & No & 70 & 15.45 \\
\hline & & Yes & 383 & 84.55 \\
\hline \multirow{4}{*}{$\begin{array}{l}\text { Experience (years of } \\
\text { holding truck driving } \\
\text { license) }\end{array}$} & expyrs & $0-5$ & 65 & 14.30 \\
\hline & & $5-10$ & 190 & 41.94 \\
\hline & & $10-15$ & 121 & 26.71 \\
\hline & & 15 and above & 77 & 16.99 \\
\hline \multirow{2}{*}{ Type of work-shift } & wrkshft & Fixed/ regular shift & 162 & 35.76 \\
\hline & & Irregular or rotating working hours & 291 & 64.24 \\
\hline \multirow{5}{*}{$\begin{array}{l}\text { Most frequent driving } \\
\text { time }\end{array}$} & wrktim & Daytime (8am-post lunch) & 162 & 35.76 \\
\hline & & Evening (post lunch-8pm) & 92 & 20.31 \\
\hline & & Night (8pm-1am) & 107 & 23.62 \\
\hline & & Late night (1am-8am) & 24 & 5.30 \\
\hline & & Any time & 68 & 15.01 \\
\hline \multirow{5}{*}{ Purpose of breaks } & brkfor & Meals only & 191 & 42.16 \\
\hline & & Rest only & 14 & 3.09 \\
\hline & & At destinations only & 65 & 14.35 \\
\hline & & Both at meals and destination & 66 & 14.57 \\
\hline & & All types & 117 & 25.83 \\
\hline
\end{tabular}




\begin{tabular}{|c|c|c|c|c|}
\hline Description & $\begin{array}{l}\text { Variable } \\
\text { Coding }\end{array}$ & Categories & $\begin{array}{l}\text { Frequency/ } \\
\text { number }\end{array}$ & $\begin{array}{l}\text { Percent } \\
(\%)\end{array}$ \\
\hline \multirow{5}{*}{$\begin{array}{l}\text { General interval of } \\
\text { taking breaks }\end{array}$} & intbrk & 1 hour or less & 72 & 15.89 \\
\hline & & $1-4$ hours & 190 & 41.94 \\
\hline & & $4-5$ hours & 113 & 24.94 \\
\hline & & $5-6$ hours & 71 & 15.67 \\
\hline & & 6 +hours & 7 & 1.55 \\
\hline \multirow{5}{*}{$\begin{array}{l}\text { Duration of sleeping per } \\
\text { day in hours }\end{array}$} & sleeph & less than 4 hours & 37 & 8.17 \\
\hline & & 4-6 hours & 126 & 27.81 \\
\hline & & 6-8 hours & 195 & 43.05 \\
\hline & & $8-10$ hours & 84 & 18.54 \\
\hline & & More than 10 hours & 11 & 2.43 \\
\hline \multirow{3}{*}{$\begin{array}{l}\text { Frequency of receiving } \\
\text { tickets for violations }\end{array}$} & Penalty & Never & 369 & 81.50 \\
\hline & & Sometimes & 70 & 15.50 \\
\hline & & Often & 14 & 3.10 \\
\hline \multirow{3}{*}{ Payment type } & payondel & Fixed monthly salary (time based) & 350 & 77.26 \\
\hline & & On completion of work (on delivery) & 84 & 18.54 \\
\hline & & On basis of kms driven (trip length) & 19 & 4.19 \\
\hline \multirow{3}{*}{$\begin{array}{l}\text { Frequency of physical } \\
\text { exercise }\end{array}$} & exercise & Never & 418 & 92.27 \\
\hline & & Sometimes (once or twice in a month) & 29 & 6.40 \\
\hline & & Very often or always & 6 & 1.32 \\
\hline \multirow{3}{*}{$\begin{array}{l}\text { Frequency of alcohol } \\
\text { consumption }\end{array}$} & drinking & Never & 376 & 83.00 \\
\hline & & Sometime (once or twice in a month) & 46 & 10.15 \\
\hline & & Often (more than two times a week) & 31 & 6.84 \\
\hline \multirow{3}{*}{$\begin{array}{l}\text { Frequency of smoking } \\
\text { per day }\end{array}$} & smoking & 0 & 245 & 54.08 \\
\hline & & $1-5$ times & 113 & 24.94 \\
\hline & & More than 5 times & 95 & 20.97 \\
\hline \multirow{2}{*}{$\begin{array}{l}\text { Sufficient rest time } \\
\text { available (self-reported) }\end{array}$} & sufresth & No & 182 & 40.18 \\
\hline & & Yes & 271 & 59.82 \\
\hline \multirow{2}{*}{$\begin{array}{l}\text { Insufficient water intake } \\
\text { (below 2L/day) }\end{array}$} & insufwat & $2 \mathrm{~L}$ or Above & 157 & 34.66 \\
\hline & & $<2 \mathrm{~L}$ (insufficient water intake) & 296 & 65.34 \\
\hline \multirow{2}{*}{$\begin{array}{l}\text { Is waiting in queues a } \\
\text { monotonous and sleep- } \\
\text { inducing task? }\end{array}$} & waiting & No & 253 & 55.85 \\
\hline & & Yes & 200 & 44.15 \\
\hline \multirow{2}{*}{$\begin{array}{l}\text { Caffeine/ tea intake per } \\
\text { day }\end{array}$} & cafperd & No & 114 & 25.17 \\
\hline & & Yes & 339 & 74.83 \\
\hline \multirow{2}{*}{$\begin{array}{l}\text { Using non-drive period } \\
\text { as rest break }\end{array}$} & ndriv_rest & No & 174 & 38.41 \\
\hline & & Yes & 279 & 61.59 \\
\hline
\end{tabular}

A total of 90 drivers reported that they fell asleep while driving in the course of the last five years and 93 reported feeling drowsy while driving at least twice a month. Out of these 90 drivers, $18 \%$ reported that they crossed the center line while driving asleep, and the majority of drivers (49\%) ran off the road (confer Figure 1). This indicates the safety-critical effect of drowsy and fatigued driving. However, only $4 \%$ of all the respondents reported accidents due to fatigue and drowsiness at the wheel. Some of the main self-perceived reasons reported by them 
for their reduced alertness and increased sleepiness while driving were insufficient rest or sleep deprivation, monotonous road conditions and inactivity, and driving for long hours.

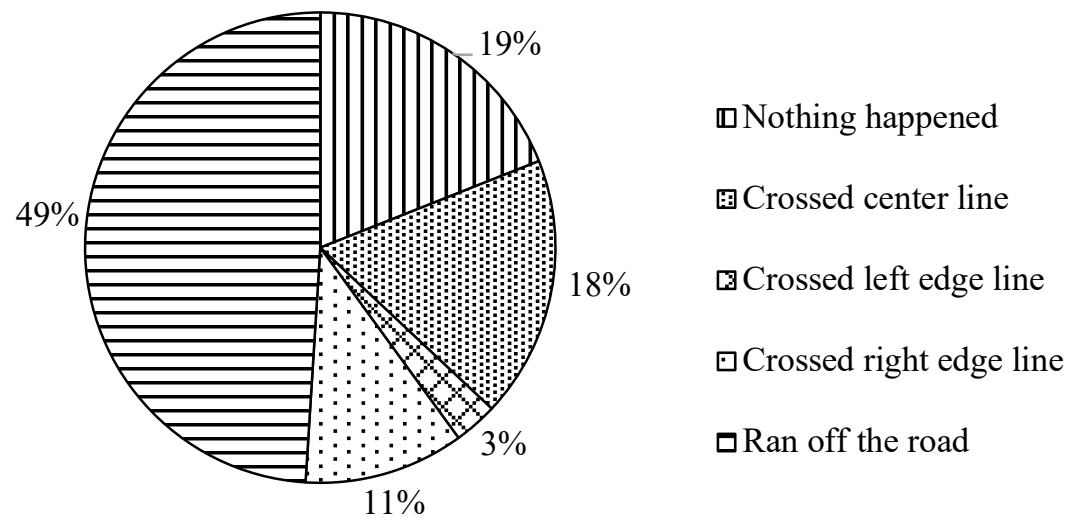

Figure 1 Effect of falling asleep at the wheel on driving as experienced by the drivers $(\mathrm{N}=90)$.

\section{Analysis and Results}

To achieve the desired objectives of the study, the following statistical analysis was performed. All the factors used in the questionnaire to test the effect of incentives on driving hours (listed in Table 5 and Appendix-A) were found significantly correlated. Therefore, Principal Component Analysis (PCA) was used to reduce the number of independent variables into uncorrelated components. Secondly, to test the differences between drowsy and non-drowsy group of drivers as a result of incentives, Kruskal-Wallis test was performed with the factors extracted using PCA. Finally, to determine the predictors of drowsy driving among long-haul truck drivers a logistic regression model was developed. The study takes into account the driver demographics, work-rest patterns, lifestyle and economic incentives as explanatory variables (as discussed in Table 2 in the literature, also confer Table 6 and Appendix-A) and driver's history of falling asleep at the wheel as the dependent variable. All the analysis was performed using IBM SPSS Statistics V22.

\section{Principal Component Analysis}

PCA is a method of orthogonal linear transformation which reduces possible correlated variables into a smaller number of variables called principal components (Maji, Velaga, \& Urie, 2018; Sullman et al., 2002; Ting et al., 2008). The initial PCA with oblimin rotation resulted in two weakly correlated factors (Pearson's correlation coefficient ' $r$ ' $<0.4$ ). Therefore, the final PCA was performed with varimax rotation to obtain uncorrelated factors. The factor analysis explained $54.51 \%$ of the variance in total. Table 5 summarizes the results of the factor analysis. The analysis resulted in two components with eigen values $>1$, and the scree plot results also supported retaining the two-factor solution (confer Figure 2). The items with very low factor loadings $(<0.1)$ were suppressed in the results. The items 1 to 5 loaded heavily on the first factor while items 6-9 loaded heavily on the second factor and item 10 moderately loaded on the second factor. 


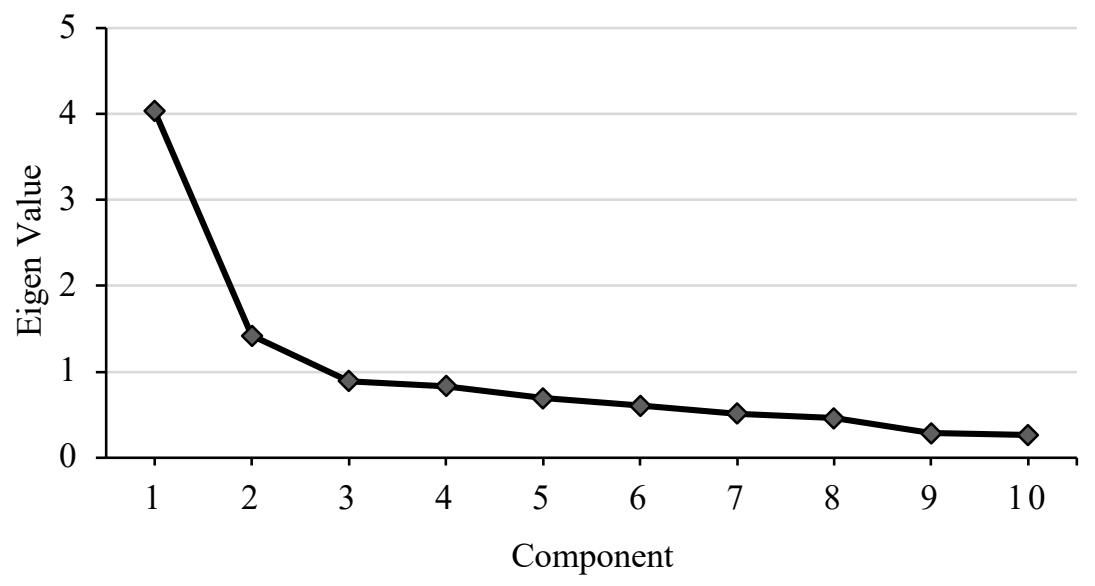

Figure 2 Scree Plot showing two major factors (Eigen Value $>1$ ) resulting from factor analysis.

The first factor contained questions enquiring about the willingness of a truck driver to earn additional monetary benefits by compromising his rest requirements (willingness to avoid breaks). Hence, motivating him to undertake long trips, short time-saving routes or night shifts are associated with drowsy driving risks. Thus, the factor was named willingness to earn extra payments (WEP).

Table 5 Factor analysis representing various payment-based motivations to drowsy driving (also confer Appendix-A).

\begin{tabular}{|c|c|c|c|c|c|}
\hline \multirow[b]{2}{*}{$\begin{array}{c}\text { Item } \\
\text { No. }\end{array}$} & \multirow[b]{2}{*}{$\begin{array}{c}\text { Description of payment related } \\
\text { motivations }\end{array}$} & \multirow[b]{2}{*}{$\begin{array}{l}\text { Frequency } \\
\text { of 'yes' } \\
(\mathbf{N}=\mathbf{4 5 3})\end{array}$} & \multirow[b]{2}{*}{$\begin{array}{l}\text { Percent } \\
(\%)\end{array}$} & \multicolumn{2}{|c|}{ Component } \\
\hline & & & & $\begin{array}{l}\text { Willingness to } \\
\text { earn extra } \\
\text { payments (WEP) }\end{array}$ & $\begin{array}{l}\text { Incentives and } \\
\text { current driving } \\
\text { (ICD) }\end{array}$ \\
\hline 1. & $\begin{array}{l}\text { Willingness to work overtime (or } \\
\text { lengthy trips) }\end{array}$ & 124 & 27.37 & 0.701 & 0.137 \\
\hline 2. & $\begin{array}{l}\text { Willingness to prefer night shift for } \\
\text { extra payment }\end{array}$ & 184 & 40.62 & 0.616 & $<0.1$ \\
\hline 3. & $\begin{array}{l}\text { Willingness to take short } \\
\text { uncomfortable routes during a lengthy } \\
\text { trip to save fuel }\end{array}$ & 168 & 37.09 & 0.724 & 0.224 \\
\hline 4. & Willingness to over speed & 105 & 23.18 & 0.765 & 0.245 \\
\hline 5. & $\begin{array}{l}\text { Willingness to avoid rest breaks in } \\
\text { lengthy trips }\end{array}$ & 110 & 24.28 & 0.746 & 0.239 \\
\hline 6. & $\begin{array}{l}\text { Additional payment for non-driving } \\
\text { works }\end{array}$ & 50 & 11.04 & 0.145 & 0.796 \\
\hline 7. & Reward for timed deliveries & 54 & 11.92 & 0.157 & 0.638 \\
\hline 8. & Penalty for late arrivals & 98 & 21.63 & 0.184 & 0.699 \\
\hline 9. & Involvement in non-driving works & 53 & 11.70 & 0.132 & 0.823 \\
\hline 10. & Time pressure & 113 & 24.94 & 0.323 & 0.558 \\
\hline \multicolumn{4}{|c|}{ Eigen values (after rotation) } & 4.032 & 1.419 \\
\hline & $\%$ Variance explained & & & 40.32 & 14.19 \\
\hline
\end{tabular}

The second factor contained questions representing the involvement of the truck driver in additional works for monetary rewards. Therefore, these items were associated with motivation to drive longer hours and compromise rest in the current driving task; this factor was named incentives associated with current driving (ICD). 


\section{Kruskal-Wallis test}

Kruskal-Wallis is a well-known non-parametric test alternative to ANOVA (Philip et al., 2002; Sabahiah et al., 2017). Keeping in line with one of the stated objectives, to examine the significant differences between the groups of drowsy and non-drowsy drivers based on the opportunities of monetary incentives, Kruskal-Wallis test was used. The test was performed with the two factors extracted using PCA. The test with the factor willingness to earn extra payments (WEP) revealed a statistically significant difference between the drivers who often fall asleep while driving $(n=90)$ and those who do not $(n=363), \chi^{2}(1, n=453)=4.46, p<0.05$. Similarly, the test with the other factor incentives associated with current driving (ICD) also revealed a

statistically significant difference between the two groups, $\chi^{2}(1, n=453)=13.24, p<0.001$. This indicates a significant association between the sleepy drivers and the role of incentives in compromising their rest breaks to work longer hours. Further, to quantitatively determine the role of different factors in causing driver sleepiness at the wheel, logistic regression was used.

\section{Logistic regression}

Logistic regression has been used to find the significant contributors of drowsy driving and sleep-related accident risk (e.g. Häkkänen and Summala, 2001; Meng et al., 2015; Papadakaki et al., 2008; Tzamalouka et al., 2005). In this study, the response to self-reported instances of drowsy driving in the past five years (lapses or incidences of nodding off even for a short while) was taken as the dichotomous dependent variable. Based on findings from the literature review (confer Table 2), the model included the following explanatory variables:

Driver demographics: age, experience of professional truck driving, education level, family responsibility which might affect driver capability to manage fatigue while driving.

Driver lifestyle: work-rest duration, interval of intermediate breaks per trip, time of the drive, sleeping duration, all routine habits of the driver related with his sleep and fatigue while driving for example, consumption of caffeine, alcohol, tobacco or water.

Driver payment motivations: involvement in non-driving works, type of payment (flat rate on delivery or trip length based). The two derived factors Willingness to earn extra payments (WEP) and incentives and current driving (ICD), were found highly correlated (correlation coefficient $>0.7$ ), therefore to avoid multicollinearity issues only one of the factors can be considered in the model. Further, chi-square test of independence showed that ICD was having higher association compared to WEP with the dependent binary variable of instances of falling asleep while driving $\left(\chi^{2}(5, \mathrm{n}=453)=28.38, \mathrm{p}<0.001\right)$. Hence, ICD was taken as one of the explanatory variables in the model.

The model was able to classify $85.2 \%$ of cases correctly keeping $95 \%$ confidence level. As shown in Table 6, categories of age (i.e., younger and middle-aged drivers), working days in a week, total driving hours, the interval of breaks between continuous driving, sleep duration, consumption of caffeine, tobacco or cigarettes and insufficient water, history of receiving a penalty for traffic rules violation and payment incentives in current driving (ICD) were found significantly associated with drowsy driving instances among long-haul truck drivers. None of 
the other factors was statistically significant. The values of pseudo R-square (Cox \& Snell $\mathrm{r}^{2}=$ .283 and Nagelkerke $r^{2}=.448$ ), suggest that the model was able to explain $28.3 \%$ to $44.8 \%$ of the variability in the dependent variable. Though the R-square values are comparable with the existing literature in this field (Bunn et al., 2005; Tzamalouka et al., 2005; Williamson \& Friswell, 2013 etc.), further larger sample size might have explained the variability in dependent variable to a greater extent.

Table 6 Logistic regression of factors associated with driver falling asleep while driving among Indian truck drivers (Dependent Variable: experiences of falling asleep at the wheel in last 5 years; $0=$ No (363), $1=$ Yes $(\mathrm{N}=90)$ )

\begin{tabular}{|c|c|c|c|c|c|c|c|}
\hline S. No. & Description & Categories & $\mathbf{B}$ & S.E. & Wald & $\begin{array}{c}\text { p- } \\
\text { value }\end{array}$ & $\begin{array}{l}\text { Odds } \\
\text { Ratio }\end{array}$ \\
\hline \multirow[t]{5}{*}{1.} & \multirow[t]{5}{*}{ Age } & 25 or below & & & 7.711 & & Ref. \\
\hline & & $26-35$ & -1.209 & .624 & 3.757 & .053 & $.299^{*}$ \\
\hline & & $36-45$ & -1.249 & .683 & 3.342 & .068 & $.287^{*}$ \\
\hline & & $46-55$ & -1.488 & .860 & 2.996 & .083 & $.226^{*}$ \\
\hline & & $56+$ & 1.005 & 1.225 & .672 & .412 & 2.731 \\
\hline \multirow[t]{4}{*}{2.} & \multirow{4}{*}{$\begin{array}{l}\text { Highest education } \\
\text { level completed }\end{array}$} & (Primary school level) Grade 5 & & & 4.466 & .215 & Ref. \\
\hline & & School up to Grade 8 & .440 & .480 & .838 & .360 & 1.552 \\
\hline & & Metric or 10th grade & .731 & .483 & 2.293 & .130 & 2.077 \\
\hline & & 12th or above & -.350 & .590 & .351 & .554 & .705 \\
\hline \multirow[t]{4}{*}{3.} & \multirow{4}{*}{$\begin{array}{l}\text { Professional truck } \\
\text { driving experience } \\
\text { (in years) }\end{array}$} & $0-5$ & & & 3.159 & & Ref. \\
\hline & & $5-10$ & -.161 & .567 & .081 & .776 & .851 \\
\hline & & $10-15$ & .533 & .623 & .731 & 393 & 1.704 \\
\hline & & 15 and above & .397 & .708 & .314 & .575 & 1.487 \\
\hline 4. & \multicolumn{2}{|l|}{ Family responsibility } & .504 & .509 & .983 & .322 & 1.655 \\
\hline 5. & \multicolumn{2}{|c|}{ Irregular type of work shift w.r.t regular or fixed work shift } & .059 & .397 & .022 & .882 & 1.061 \\
\hline 6. & \multicolumn{2}{|c|}{ Number of total working hours per day } & -.015 & .034 & .182 & 670 & .985 \\
\hline 7. & \multicolumn{2}{|c|}{ Number of working days per week } & -.342 & .195 & 3.089 & .079 & $.710^{*}$ \\
\hline \multirow[t]{5}{*}{8.} & \multirow{5}{*}{$\begin{array}{l}\text { Most frequent } \\
\text { driving time of the } \\
\text { day }\end{array}$} & Daytime (8am-lunch) & & & 5.433 & & Ref. \\
\hline & & Evening (post lunch-8pm) & -.184 & .496 & .138 & .711 & .832 \\
\hline & & Night (8pm-1am) & -.365 & .486 & .563 & .453 & .694 \\
\hline & & Early morning(1am-8am) & .229 & .703 & .106 & .745 & 1.257 \\
\hline & & Any time & -1.132 & .524 & 4.667 & .031 & $.322^{* *}$ \\
\hline 9. & \multicolumn{2}{|c|}{ Number of driving hours per day } & .421 & .083 & 25.714 & .000 & $1.523^{* * *}$ \\
\hline \multirow[t]{5}{*}{10.} & \multirow{5}{*}{$\begin{array}{l}\text { Types of in between } \\
\text { breaks }\end{array}$} & Only for meals & & & 12.449 & .014 & Ref. \\
\hline & & Only for rest & .612 & 1.201 & .259 & .611 & 1.843 \\
\hline & & Only after reaching destination & -.410 & .547 & .561 & .454 & .664 \\
\hline & & Both at meals and destination & -.540 & .562 & .923 & .337 & .583 \\
\hline & & All types & -1.645 & .496 & 10.985 & .001 & $.193^{* * *}$ \\
\hline \multirow[t]{5}{*}{11.} & \multirow{5}{*}{$\begin{array}{l}\text { Continuous driving } \\
\text { hours without any } \\
\text { break ( } 15 \text { min or } \\
\text { more) in general }\end{array}$} & Up to 1 hour & & & 8.641 & .071 & Ref. \\
\hline & & Up to 4 hours & 1.231 & .624 & 3.888 & .049 & $3.425^{* *}$ \\
\hline & & $4-5$ hours & 1.043 & .688 & 2.298 & .130 & 2.839 \\
\hline & & $5-6$ hours & 1.126 & .733 & 2.358 & .125 & 3.083 \\
\hline & & $6+$ hours & 3.008 & 1.072 & 7.872 & .005 & $20.24^{* * *}$ \\
\hline \multirow[t]{5}{*}{12.} & \multirow{5}{*}{$\begin{array}{l}\text { Average number of } \\
\text { hours slept per day } \\
\text { in general }\end{array}$} & Less than 4 hours & & & 10.116 & .039 & Ref. \\
\hline & & 4-6 hours & -.622 & .574 & 1.175 & .278 & .537 \\
\hline & & 6-8 hours & -1.571 & .605 & 6.746 & .009 & $.208^{* * *}$ \\
\hline & & $8-10$ hours & -.771 & .652 & 1.396 & .237 & .463 \\
\hline & & More than 10 hours & -1.662 & 1.107 & 2.256 & .133 & .190 \\
\hline 13. & \multicolumn{2}{|c|}{ Using non-drive period as rest break } & .184 & .376 & .239 & .625 & 1.202 \\
\hline 14. & \multirow{2}{*}{\multicolumn{2}{|c|}{$\begin{array}{l}\text { Rest time provided by owner is sufficient to alleviate stress } \\
\text { Waiting in queues a monotonous and sleep inducing task }\end{array}$}} & -.317 & .384 & .682 & .409 & .728 \\
\hline 15. & & & .304 & .351 & .751 & .386 & 1.355 \\
\hline
\end{tabular}




\begin{tabular}{|c|c|c|c|c|c|c|c|}
\hline S. No. & Description & Categories & $\mathbf{B}$ & S.E. & Wald & $\begin{array}{c}\text { p- } \\
\text { value }\end{array}$ & $\begin{array}{l}\text { Odds } \\
\text { Ratio }\end{array}$ \\
\hline 16. & \multicolumn{2}{|c|}{ Caffeine/ tea intake per day } & 1.042 & .540 & 3.722 & .054 & $2.835^{*}$ \\
\hline \multirow[t]{3}{*}{17.} & \multirow{3}{*}{$\begin{array}{l}\text { Frequency of } \\
\text { alcohol consumption }\end{array}$} & Never & & & 1.538 & .464 & Ref. \\
\hline & & Sometimes & .229 & .533 & .184 & .668 & 1.257 \\
\hline & & Often & .775 & .631 & 1.507 & .220 & 2.170 \\
\hline \multirow[t]{3}{*}{18.} & \multirow{3}{*}{$\begin{array}{l}\text { Intake of cig/ } \\
\text { tobacco per day }\end{array}$} & 0 & & & 6.193 & .045 & Ref. \\
\hline & & $1-5$ times & .882 & .380 & 5.389 & .020 & $2.415^{* *}$ \\
\hline & & More than 5 times & .119 & .465 & .065 & .798 & 1.126 \\
\hline \multirow[t]{3}{*}{19.} & \multirow{3}{*}{$\begin{array}{l}\text { Physical exercise or } \\
\text { activities }\end{array}$} & Never & & & .700 & .705 & Ref. \\
\hline & & Sometimes (once or twice in a month) & -.231 & .564 & .168 & .682 & .794 \\
\hline & & Very often or always & .873 & 1.198 & .531 & .466 & 2.393 \\
\hline 20. & \multicolumn{2}{|c|}{ Insufficient water intake (below 2L/day) } & 1.650 & .502 & 10.820 & .001 & $5.207^{* * *}$ \\
\hline 21. & \multicolumn{2}{|c|}{ Body Mass Index (BMI) } & -.008 & .038 & .047 & .829 & .992 \\
\hline \multirow[t]{3}{*}{22.} & \multirow{3}{*}{$\begin{array}{l}\text { Frequency of getting } \\
\text { tickets for violations }\end{array}$} & Never & & & 8.247 & .016 & Ref. \\
\hline & & Sometimes (once or twice in a week) & .885 & .388 & 5.222 & .022 & $2.424^{* *}$ \\
\hline & & Very often or always & 1.760 & .878 & 4.016 & .045 & $\mathbf{5 . 8 1 0}^{\text {*** }}$ \\
\hline \multirow[t]{3}{*}{23.} & \multirow[t]{3}{*}{ Type of salary } & Fixed monthly salary & & & .322 & .851 & Ref. \\
\hline & & On completion of work (on delivery) & -.212 & .427 & .247 & .619 & .809 \\
\hline & & On the basis of kms driven & .132 & .708 & .035 & .853 & 1.141 \\
\hline 24. & \multicolumn{2}{|c|}{ Incentives and current driving (ICD) } & .455 & .163 & 7.805 & .005 & $1.577^{* * *}$ \\
\hline 25. & \multicolumn{2}{|l|}{ Intercept } & -4.962 & 2.014 & 6.067 & .014 & .007 \\
\hline
\end{tabular}

Ref.: 'Reference category'; ‘*’ $p<0.1$; “**’ $p<0.05$; ‘***’ $p<0.01$

Overall model $\chi^{2}(48, N=453)=150.566, p<0.001$; Hosmer and Lemeshow test $\chi^{2}(8)=6.322, p=0.611$; Nagelkerke $r^{2}=44.8 \%$ and Cox and Snell $r^{2}=28.3 \%$.

\section{Discussion}

The results show that driver lifestyle and financial factors play a significant role in driver drowsiness while driving. They are further discussed below.

\subsection{Influence of driver background factors}

Drivers between $25-36,36-45$ and $46-55$ years were found at $70 \%, 71 \%$ and $77 \%$ less risk of drowsy driving respectively, compared to young and novice drivers below 25 years. This might be explained by the lesser experience of young drivers to curb the effects of sleepiness compared to older drivers (Smith et al., 2009). Another possibility could be that young drivers preferred to get involved in long-duration trips due to more eagerness to earn money (Campos Monteiro et al., 2015). Duke et al. (2010) also reported similar findings that drowsiness symptoms show a ushaped curve with driver's age. Most of the middle-aged drivers were married therefore associated responsibility of family or partner might have encouraged them to drive cautiously. However, the variable family responsibility in the proposed hypothesis was found insignificant in the current study. Driving experience and driver education status did not make a significant contribution in the model contrary to the findings in some of the previous studies (Barr et al., 2005; Sullman et al., 2002). The possible reason for this might be that the current sample did not cover a range of variability among these variables for comparison. However, Zhang et al. (2016) have also reported education and experience as insignificant variables in their study. 


\subsection{Influence of work-rest pattern}

The truck drivers in the current sample spent almost 14-hours a day on duty and most of the time was spent in driving. Moreover, the drivers reported being on duty for the entire week without any holidays, thereby not allowing them sufficient time to rest. Therefore, the drivers violated the 'in-between rest breaks' and 'minimum rest duration' as stated in HOS rules (confer Table 1). As per model results, the additional working days in a week were associated with decrease in odds of sleepiness (confer Table 6). However, according to the model results, each additional hour of driving increased the odds of sleepy lapses at the wheel by 1.5 times (Figure 3).

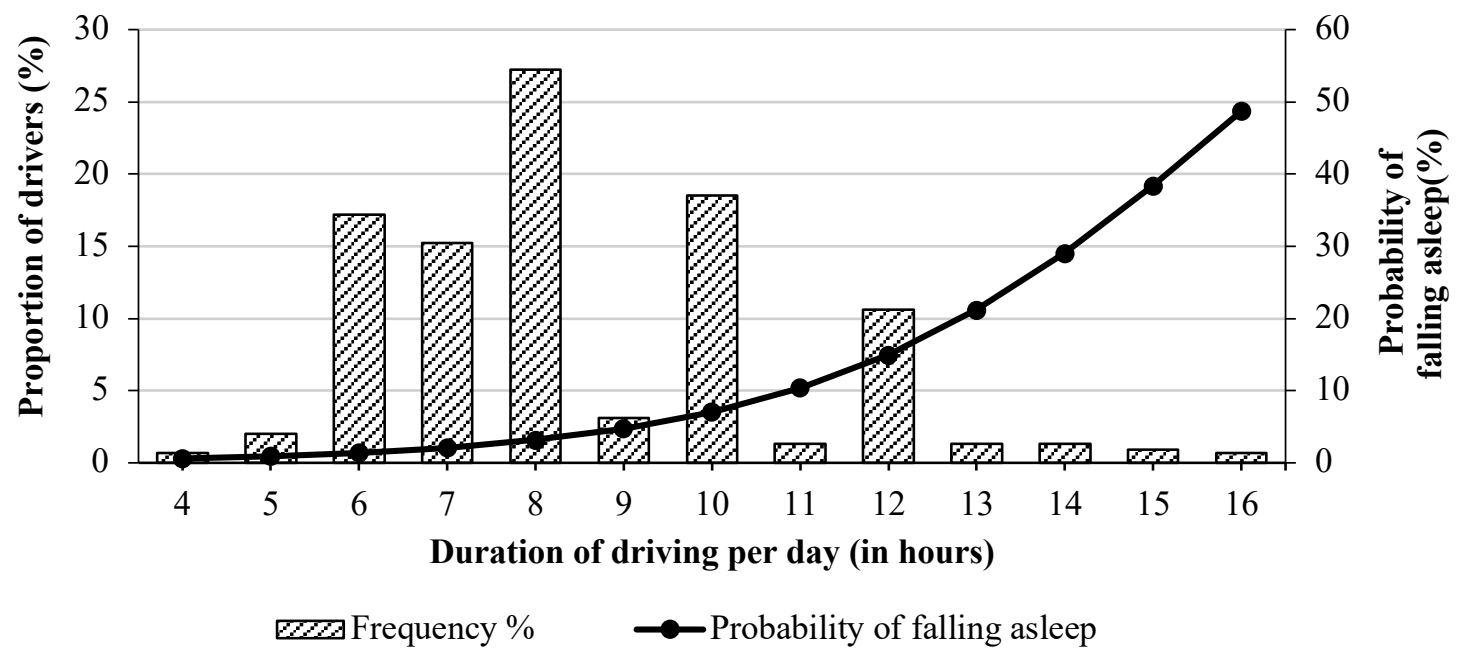

Figure 3 Probability of falling asleep with duration of driving per day

Similarly, Arnold et al. (1997) and Knutsson et al. (2008) have also reported that longer driving hours increase the probability of sleepy lapses while driving. Therefore, it can be implied that the odds of driver drowsiness are more significantly affected by duration of driving than the number of working days. Interestingly, the results also showed that as the continuous hours of driving without taking any breaks increased beyond 6-h, the odds of sleepiness at the wheel increased heavily. This might be a result of 'accumulated fatigue' among the drivers due to long and continuous hours of driving (May \& Baldwin, 2009). According to previous studies, driving during the night time and after lunch have been significantly associated with higher decrement in driver alertness during a day (Gastaldi, Rossi, \& Gecchele, 2014; Sagaspe et al., 2008; Thiffault \& Bergeron, 2003; G. Zhang, Yau, Zhang, \& Li, 2016; H. Zhang et al., 2014). However, in the current study, the time of drive was enquired from the drivers on the basis of the start time of their shift. This might be the reason that the 'time of drive' did not contribute significantly to the model.

In previous studies, sleeping duration less than seven hours has been associated with increased cases of drowsy driving crashes among truck drivers (Tzamalouka et al., 2005). Drivers who were partially sleep deprived (sleeping less than 4-h daily) were found to be at 4.8 folds higher risk of falling asleep at the wheel as compared to the sufficiently sleeping (6-8 hours) drivers. Similarly, Maia et al. (2013) also found that as compared to the drivers taking appropriate sleep 
of $7 \mathrm{~h}$, the drivers taking short (6h) and very short $(<5 \mathrm{~h})$ duration of sleep were at 2 and 3.8 times higher risk of drowsy driving respectively. Therefore, the proposed hypothesis regarding the negative effects of violation of HOS rules and extended driving hours was found to be true.

\subsection{Influence of driver lifestyle}

The results of the regression analysis emphasized the association of higher intake of caffeinated beverages while driving (minimum three times a day) with increased odds of sleepiness among Indian truck drivers. Similarly, the higher intake of tobacco or cigarettes while driving (smoking about 1-5 times a day) compared to non-smokers was associated with 2.4 times increased sleepiness among the drivers. The drivers might have increased the consumption of tobacco and caffeine as they recognized any decrement in their alertness while driving (Watling et al. 2014; Howard et al. 2014; Johnson et al. 2015). Contrary to the results obtained by Du et al. (2016), consumption of alcohol was found insignificant in the analysis. This might be owed to underreporting of such events by the drivers, due to public shyness to disclose their drinking habits during a face-to-face interview survey. Majority of the drivers (93\%) did not involve in any physical exercise, this might be the reason that the model could not deduce any effect of exercise on driver alertness. Apart from caffeine intake and smoking as sleepiness countermeasures, consumption of water is also one of the effective countermeasures to fight fatigue and sleepiness (McKernon 2009; Pylkkönen et al. 2015). Therefore, insufficient consumption of water per day (minimum of 2L/day for fulfilling metabolic needs) might also be responsible for increased odds of sleepiness while driving in the current study (confer Table 6). Thus, the proposed hypothesis was found partially true. A higher urge for caffeine and smoking indicate increased sleepiness while sufficient water intake can be used as a way to maintain alertness while driving.

\subsection{Influence of payment and incentives}

Thompson, Newnam, and Stevenson (2015) have found that drivers who were paid 'per km' were involved in longer driving periods without any rest breaks or sleeping and also involved in a higher number of crashes compared to drivers who were paid 'flat rate' or 'per trip'. Also, in the previous studies, opportunities for the extra monetary benefits for non-driving works have been associated with longer driving hours and driver sleepiness (Williamson \& Friswell 2013). The drivers were asked multiple questions in the survey regarding the influence of the type of payment and additional incentives motivating their extended working hours (confer Table 5). As shown in the regression results in Table 6, the odds of sleepiness among drivers increased by 1.5 times for drivers scoring high on the factor 'Incentives in current driving (ICD)' (Figure 4). Therefore, it may also be concluded that incentives for early or on-time deliveries with the aim of increasing productivity might have motivated the truckers to drive longer hours. In the current sample, a very large proportion of truck drivers $(85 \%)$ had associated financial responsibilities of their families or they were 'the sole earners' which might be the reason for their inclination towards earning incentives. Moreover, the majority of drivers were less educated (64\% below $10^{\text {th }}$ standard) to understand the risks of avoiding proper sleep and rest. This is also indicated by 
their involvement in frequent violations varying from 'sometimes' to 'often' with increased odds of sleepiness by 2.4 to 5.8 times respectively compared to non-violators (Table 6).

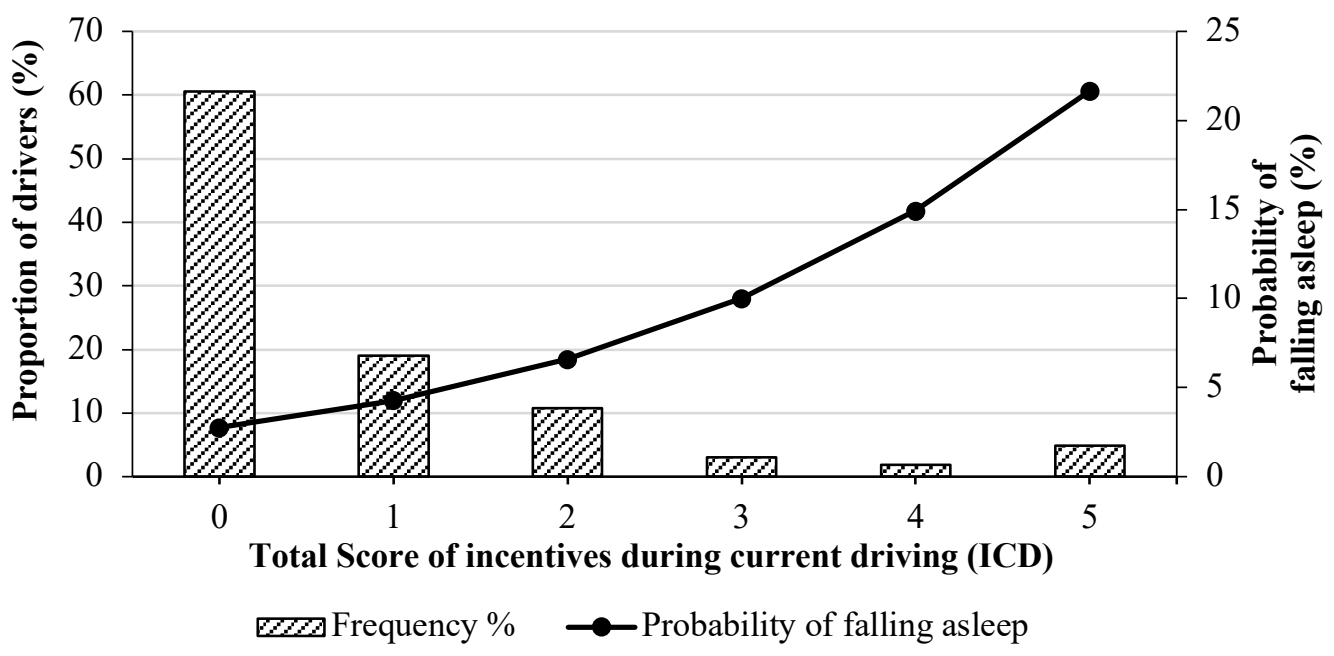

Figure 4 Probability of falling asleep at the wheel while driving with incentives during current driving (ICD)

\subsection{Methodological limitations}

A possible limitation of the study is the comparatively low variance in certain variables (such as education) in the current data to draw a comparison between different drivers. The survey was interview based and relied completely on driver's self-perception about fatigue and other questions. Therefore, the sample can be response biased due to comparatively low participation rate. A major challenge in collecting large sample size in such studies is to convince reluctant truck drivers to stop and participate in the survey or stay till the completion of survey. The sample size considered in the current study may not be representative of the entire population of truck drivers. Future studies can focus on these factors considering a further large sample size. Also, Asian Institute of Transport Development (AITD) (2000) states that power steering helps in reducing the driver fatigue and the driver response time compared to manual steering. The effect of such mechanical factors can also be covered in the future research. In case of long-haul truck drivers, the drivers are involved in long journeys and spend days or weeks away from their families. Therefore, further the effect of sexual lifestyle of such drivers on driving performance is also an interesting field to explore in future research. In a developing country such as India, there is a financial dependence of family members on the drivers as 'the sole earners' of the family particularly, in case of low educated and unemployed families. Such family responsibilities on the drivers may also motivate them to indulge in overtime and violation of 'hours of service' rules for monetary incentives. Thus, the role of family responsibility among drivers can indirectly serve as a potential challenge to traffic safety in developing countries.

\section{Conclusion}

The rate of violations of HOS rules and holding license without mandatory educational qualification show the lack of stringent enforcement actions by the authorities. As a result of the violations of HOS rules, the drivers are found to be involved in incidents of falling asleep at the 
wheel. The results of the study emphasize the negative effects of payment incentives to driver safety and fatigue management. This study shows that the payment system of freight employers and companies is mostly productivity driven ( $22 \%$ receive pay with a task or trip completion and majority is interested in earning incentives). The non-driving tasks like loading/unloading or waiting in queues are not counted for payments for most of the long-haul truck drivers according to the current survey. However, being time-bounded for deliveries, any likelihood of financial rewards or penalties has been certainly found to influence their duration of work and rest. This influences their fatigue risk management while driving as they compromise their essential resting hours for additional productivity. According to regression results, the drivers receiving incentives in current driving faced 1.58 times higher odds of falling asleep while driving, which proves the novelty of the concept of economic motivations proposed in this study. The drivers who are able to manage their fatigue and sleepiness by avoiding additional works for incentives, and taking adequate rest and breaks are expected to be comparatively safer towards sleepy driving risks. Therefore, the freight companies shall be encouraged to reduce the pressure of incentives-based driving on the long-haul freight transport drivers. Investigating further the role of payment incentives in motivating the drivers to engage in risky and unsafe driving practices, committing traffic violations under pressure of timeliness in their trips would be a useful topic for future research.

\section{Acknowledgement}

This research has been made available through the European Union Europe Aid-funded Project "EU-India Research \& Innovation Partnership for Efficient and Sustainable Freight Transportation (REINVEST)," Contract Number: R/141842. The contents of this publication are the sole responsibility of the authors of this paper and can in no way be taken to reflect the views of the European Union.

\section{References}

Adams-guppy, J., \& Guppy, A. (2003). Truck driver fatigue risk assessment and management: a $\begin{array}{llll}\text { multinational } & \text { survey. } & \text { Ergonomics, } & 46(8),\end{array}$ https://doi.org/10.1080/0014013021000056980

Aidman, E., Chadunow, C., Johnson, K., \& Reece, J. (2015). Real-time driver drowsiness feedback improves driver alertness and self-reported driving performance. Accident Analysis and Prevention, 81, 8-13. https://doi.org/10.1016/j.aap.2015.03.041

Al-Houqani, M., Eid, H. O., \& Abu-Zidan, F. M. (2013). Sleep-related collisions in United Arab Emirates. Accident Analysis and Prevention, 50, 1052-1055. https://doi.org/10.1016/j.aap.2012.08.010

Alonso, F., Esteban, C., Useche, S. A., \& Cózar, E. L. De. (2016). Prevalence of Physical and Mental Fatigue Symptoms on Spanish Drivers and Its Incidence on Driving Safety. Advances in Psychology and Neuroscience, 1(2), 10-18. https://doi.org/10.11648/j.apn.20160102.12

Anne G. Wheaton, Chapman, D. P., Presley-Cantrell, L. R., Croft, J. B., \& Roehler, D. R. 
(2013). Drowsy Driving - 19 States and the District of Columbia, 2009-2010. MMWR. Morbidity and Mortality Weekly Report, 61(51), 1033-7. Retrieved from http://www.ncbi.nlm.nih.gov/pubmed/23282860

Anund, A., Kecklund, G., \& Åkerstedt, T. (2011). Sleepiness, crashes and the effectiveness of countermeasures. Swedish National Road and Transport Research Institute (VTI) (Vol. Vol.21 Sup).

Arnold, P. K., Hartley, L. R., Corry, A., Hochstadt, D., Penna, F., \& Feyer, A. M. (1997). Hours of work, and perceptions of fatigue among truck drivers. Accident Analysis and Prevention, 29(4 SPEC. ISS.), 471-477. https://doi.org/10.1016/S0001-4575(97)00026-2

Asian Institute of Transport Development (AITD). (2000). Technology Change: Slow and Unsteady. In H. Bhaya, K. L. Thapar, S. R. Hashim, Y. K. Alagh, D. Mohan, \& S. Raghavan (Eds.), INDIAN TRUCKING (Vol. 7, pp. 44-52). Asian Institute of Transport Development.

Asian Institute of Transport Development (AITD). (2015). Study on Trucking Operations in India - Problems \& Potential. Asian Institute of Transport Development (AITD) \& Central Instituet of Road Transport.

Barr, L. C., Yang, C. Y. D., Hanowski, R. J., \& Olson, R. (2005). Assessment of Driver Fatigue, Distraction, and Performance in a Naturalistic Setting. Transportation Research Record, 1937, 51-60. https://doi.org/10.3141/1937-08

Bener, A., Crundall, D., Haigney, D., Bensiali, A. K., \& Al-Falasi, A. S. (2007). Driving behaviour, lapses, errors and violations on the road: United Arab Emirates study. Advances in Transportation Studies, (12), 5-14.

Blanco, M., Hanowski, R. J., Olson, R. L., Morgan, J. F., Soccolich, S. a., Wu, S.-C., \& Guo, F. (2011). The impact of driving, non-driving work, and rest breaks on driving performance in commercial motor vehicle operations. https://doi.org/10.1037/e625382011-001

Blower, D., Green, P., \& Matteson, A. (2010). Condition of trucks and truck crash involvement. Transportation Research Record: Journal of the Transportation Research Board, 2194(2194), 21-28. https://doi.org/10.3141/2194-03

British Columbia Truckers Association (BCTA). (2013). INTERNATIONAL TRUCKING REFERENCE: ROADS, RULES, AND DRIVERS.

Brower, K. J. (2009). Alcohol' s Effects on Sleep in Alcoholics. Alcohol Research \& Health, 25(2), 110-125.

Bunn, T. L., Slavova, S., Struttmann, T. W., \& Browning, S. R. (2005). Sleepiness/fatigue and distraction/inattention as factors for fatal versus nonfatal commercial motor vehicle driver injuries. Accident Analysis and Prevention, 37(5), 862-869. https://doi.org/10.1016/j.aap.2005.04.004

Campos Monteiro, D. L., Peñaloza, V., Pinto, F. R., Denegri Coria, M. del C., \& Orellana Calderón, L. M. (2015). Attitudes towards money and motivational orientation to work in Brazilian young workers. Contaduría y Administración, 60(1), 11-30. https://doi.org/10.1016/S0186-1042(15)72145-5 
Cantor, D. E., Corsi, T. M., Grimm, C. M., \& Ozpolat, K. (2010). A driver focused truck crash prediction model. Transportation Research Part E: Logistics and Transportation Review, 46(5), 683-692. https://doi.org/10.1016/j.tre.2009.08.011

Castillo-Manzano, J. I., Castro-Nuño, M., \& Fageda, X. (2016). Exploring the relationship between truck load capacity and traffic accidents in the European Union. Transportation Research Part E: Logistics and Transportation Review, 88, 94-109. https://doi.org/10.1016/j.tre.2016.02.003

Chen, G. X., Fang, Y., Guo, F., \& Hanowski, R. J. (2016). The influence of daily sleep patterns of commercial truck drivers on driving performance. Accident Analysis and Prevention, 91, 55-63. https://doi.org/10.1016/j.aap.2016.02.027

Department of Economic and Social Affairs, U. (2017). Household Size and Composition Around the World 2017-Data Booklet (ST/ESA/ SER.A/405). https://doi.org/10.3390/atmos6091362

Di Milia, L., Smolensky, M. H., Costa, G., Howarth, H. D., Ohayon, M. M., \& Philip, P. (2011). Demographic factors, fatigue, and driving accidents: An examination of the published literature. Accident Analysis and Prevention, 43(2), 516-532. https://doi.org/10.1016/j.aap.2009.12.018

Dogan, E., Steg, L., \& Delhomme, P. (2011). The influence of multiple goals on driving behavior: The case of safety, time saving, and fuel saving. Accident Analysis and Prevention, 43(5), 1635-1643. https://doi.org/10.1016/j.aap.2011.03.002

Du, H., Zhao, X., Zhang, G., \& Rong, J. (2016). Effects of Alcohol and Fatigue on Driving Performance in Different Roadway Geometries. Transportation Research Record, 88-96. https://doi.org/10.3141/2584-11

Duke, J., Guest, M., \& Boggess, M. (2010). Age-related safety in professional heavy vehicle drivers: A literature review. Accident Analysis and Prevention, 42(2), 364-371. https://doi.org/10.1016/j.aap.2009.09.026

Ericsson, E., Larsson, H., \& Brundell-Freij, K. (2006). Optimizing route choice for lowest fuel consumption - Potential effects of a new driver support tool. Transportation Research Part C: Emerging Technologies, 14(6), 369-383. https://doi.org/10.1016/j.trc.2006.10.001

Federal Motor Carrier Safety Administration. (2015). Interstate Truck Driver's Guide to Hours of Service. Retrieved from http:/www.fmcsa.dot.gov/rules-regulations/truck/driver/hos/ fmcsa-guide-to-hos.pdf

Gastaldi, M., Rossi, R., \& Gecchele, G. (2014). Effects of driver task-related fatigue on driving performance. Procedia - Social and Behavioral Sciences, 111, 955-964. https://doi.org/10.1016/j.sbspro.2014.01.130

Girotto, E., Andrade, S. M. de, Gonzalez, A. D., \& Mesas, A. E. (2016). Professional experience and traffic accidents/near-miss accidents among truck drivers. Accident Analysis and Prevention, 95, 299-304. https://doi.org/10.1016/j.aap.2016.07.004

Government of India, \& Ministry of Labour and Employment. The Motor Transport Workers Act, 1961 (1988). India. 
Häkkänen, H., \& Summala, H. (2001). Fatal traffic accidents among trailer truck drivers and accident causes as viewed by other truck drivers. Accident Analysis and Prevention, 33(2), 187-196. https://doi.org/10.1016/S0001-4575(00)00030-0

Highway Traffic Safety Administration, N., \& Department of Transportation, U. (2015). TRAFFIC SAFETY FACTS Early Estimate of Motor Vehicle Traffic Fatalities in 2015, (July), 2013-2016.

Howard, M. E., Jackson, M. L., Berlowitz, D., O’Donoghue, F., Swann, P., Westlake, J., ... Pierce, R. J. (2014). Specific sleepiness symptoms are indicators of performance impairment during sleep deprivation. Accident Analysis and Prevention, 62, 1-8. https://doi.org/10.1016/j.aap.2013.09.003

Indian Institute of Management Calcutta. (2009). Operational efficiency of national highways for freight transportation in India. Delhi, India. Retrieved from http://www.tcil.com/tcil/pdf/tci \& iim study report.pdfF

Johns, M. W. (2000). A sleep physiologist's view of the drowsy driver. Transportation Research Part F, 3(4), 241-249. https://doi.org/10.1016/S1369-8478(01)00008-0

Johnson, K. D., Patel, S. R., Baur, D. M., Edens, E., Sherry, P., Malhotra, A., \& Kales, S. N. (2015). Association of Sleep Habits With Accidents and Near Misses in United States Transportation Operators. Journal of Occup Environ Med, 33(4), 395-401. https://doi.org/10.1038/nbt.3121.ChIP-nexus

Kanazawa, H., Suzuki, M., Onoda, T., \& Yokozawa, N. (2006). Excess workload and sleeprelated symptoms among commercial long-haul truck drivers. Sleep and Biological Rhythms, 4(2), 121-128. https://doi.org/10.1111/j.1479-8425.2006.00218.x

Knutsson, A., Westerholm, P., Theorell, T., Alfredsson, L., Kecklund, G., Åkerstedt, T., ... Kecklund, G. (2002). Sleep disturbances, work stress and work hours: A cross-sectional study. Journal of Psychosomatic Research, 53(3), 741-748. https://doi.org/10.1016/S00223999(02)00333-1

Lauper, E., Moser, S., Fischer, M., Matthies, E., \& Kaufmann-Hayoz, R. (2015). Psychological predictors of eco-driving: A longitudinal study. Transportation Research Part F: Traffic Psychology and Behaviour, 33, 27-37. https://doi.org/10.1016/j.trf.2015.06.005

Lin, T., Jovanis, P. P., \& Yang, C. (1984). Modeling the Safety of Truck Driver Service Hours Using Time-Dependent Logistic Regression Il.

Maia, Q., Grandner, M. A., Findley, J., \& Gurubhagavatula, I. (2013). Short and long sleep duration and risk of drowsy driving and the role of subjective sleep insufficiency. Accident Analysis and Prevention, 59, 618-622. https://doi.org/10.1016/j.aap.2013.07.028

Maji, A., Velaga, N. R., Urie, U., (2018) Hierarchical clustering analysis framework of mutually exclusive crash causation parameters for regional road safety strategies, International Journal of Injury Control and Safety Promotion, 25:3, 257-271, DOI: 10.1080/17457300.2017.1416485

Matthews, R. W., Ferguson, S. A., Zhou, X., Kosmadopoulos, A., Kennaway, D. J., \& Roach, G. D. (2012). Simulated driving under the influence of extended wake, time of day and sleep restriction. Accident Analysis and Prevention, 45(SUPPL.), 55-61. 
https://doi.org/10.1016/j.aap.2011.09.027

May, J. F., \& Baldwin, C. L. (2009). Driver fatigue: The importance of identifying causal factors of fatigue when considering detection and countermeasure technologies. Transportation Research Part F: Traffic Psychology and Behaviour, 12(3), 218-224. https://doi.org/10.1016/j.trf.2008.11.005

McCartt, A. T., Ribner, S. A., Pack, A. I., \& Hammer, M. C. (1996). The scope and nature of the drowsy driving problem in New York state. Accident Analysis and Prevention, 28(4), 511517. https://doi.org/10.1016/0001-4575(96)00021-8

McCartt, A. T., Rohrbaugh, J. W., Hammer, M. C., \& Fuller, S. Z. (2000). Factors associated with falling asleep at the wheel among long-distance truck drivers. Accident Analysis and Prevention, 32(4), 493-504. https://doi.org/10.1016/S0001-4575(99)00067-6

McKernon, S. (2008). A literature review on driver fatigue among drivers in the general public. NZ Transport Agency research report 342. Retrieved from http://www.nzta.govt.nz

Medvedev, D., Shome, S., Seth, S., \& Misra, J. (2014). India Development Update. The World Bank Group. Macroeconomics and Fiscal Management.

Meng, F., Li, S., Cao, L., Li, M., Peng, Q., Wang, C., \& Zhang, W. (2015). Driving fatigue in professional drivers: a survey of truck and taxi drivers. Traffic Injury Prevention, 16(5), 474-83. https://doi.org/10.1080/15389588.2014.973945

Mills, P. J., Kim, J. H., Bardwell, W., Hong, S., \& Dimsdale, J. E. (2008). Predictors of fatigue in obstructive sleep apnea. Sleep and Breathing, 12(4), 397-399. https://doi.org/10.1007/s11325-008-0192-8

Ministry of Labour \& Employment. (2008). Report on the Working of the Motor Transport Workers Act, 1961 for the Year 2008.

Mitra, S. (2009). Operational efficiency of national highways for freight transportation in India. Delhi, India. Retrieved from http://www.tcil.com/tcil/pdf/tci \& iim study report.pdf

Morrow, P. C., \& Crum, M. R. (2004). Antecedents of fatigue, close calls, and crashes among commercial motor-vehicle drivers. Journal of Safety Research, 35(1), 59-69. https://doi.org/10.1016/j.jsr.2003.07.004

National Crime Records Bureau. (2015). Accidental Deaths \& Suicides in India, 2015. Retrieved from http://ncrb.gov.in

National Road Safety Strategy. (2011). Australian Transport Council. Retrieved from http://roadsafety.gov.au/nrss/files/NRSS_2011_2020.pdf

Newnam, S., Mamo, W. G., \& Tulu, G. S. (2014). Exploring differences in driving behaviour across age and years of education of taxi drivers in Addis Ababa, Ethiopia. Safety Science, 68, 1-5. https://doi.org/10.1016/j.ssci.2014.02.012

Nordbakke, S., \& Sagberg, F. (2007). Sleepy at the wheel: Knowledge, symptoms and behaviour among car drivers. Transportation Research Part F: Traffic Psychology and Behaviour, 10(1), 1-10. https://doi.org/10.1016/j.trf.2006.03.003

Otmani, S., Roge, J., \& Muzet, A. (2005). Sleepiness in professional drivers: Effect of age and 
time of day. Accident Analysis and Prevention, 37(5), 930-937. https://doi.org/10.1016/j.aap.2005.04.011

Papadakaki, M., Kontogiannis, T., Tzamalouka, G., Darviri, C., \& Chliaoutakis, J. (2008). Exploring the effects of lifestyle, sleep factors and driving behaviors on sleep-related road risk: A study of Greek drivers. Accident Analysis and Prevention, 40(6), 2029-2036. https://doi.org/10.1016/j.aap.2008.08.019

Pérez-Chada, D., Videla, A. J., O’Flaherty, M. E., Palermo, P., Meoni, J., Sarchi, M. I., ... Sarchi, M. I. (2005). Sleep habits and accident risk among truck drivers: a cross-sectional study in Argentina. Sleep, 28(9), 1103-1108. https://doi.org/10.1016/S87563452(08)70700-X

Philip, P., Taillard, J., Léger, D., Diefenbach, K., Akerstedt, T., Bioulac, B., \& Guilleminault, C. (2002). Work and rest sleep schedules of 227 European truck drivers. Sleep Medicine, 3(6), 507-511. https://doi.org/10.1016/S1389-9457(02)00138-7

Phillips, R. O. (2015). A review of definitions of fatigue - And a step towards a whole definition. Transportation Research Part F: Traffic Psychology and Behaviour, 29, 48-56. https://doi.org/10.1016/j.trf.2015.01.003

Phillips, R. O., Kecklund, G., Anund, A., \& Sallinen, M. (2017). Fatigue in transport: a review of exposure, risks, checks and controls. Transport Reviews, 37(6), 742-766. https://doi.org/10.1080/01441647.2017.1349844

Pylkkönen, M., Sihvola, M., Hyvärinen, H. K., Puttonen, S., Hublin, C., \& Sallinen, M. (2015). Sleepiness, sleep, and use of sleepiness countermeasures in shift-working long-haul truck drivers. Accident Analysis and Prevention, 80, 201-210. https://doi.org/10.1016/j.aap.2015.03.031

Raghuram, G. (2015). An Overview of the Trucking Sector in India: Significance and Structure. Trucking Business Management: Cases and Concepts.

Reason, J., Manstead, A., Stradling, S., Baxter, J., Campbell, K., Reason, J., ... Campbell, K. (1990). Errors and violations on the roads: a real distinction? Ergonomics, 33(10/11), 1315-1332. https://doi.org/10.1080/00140139008925335

Road Safety Authority. (2006). Guide to EU Rules on Driver's Hours Regulation.

Ronen, A., Chassidim, H. S., Gershon, P., Parmet, Y., Rabinovich, A., Bar-Hamburger, R., ... Shinar, D. (2010). The effect of alcohol, THC and their combination on perceived effects, willingness to drive and performance of driving and non-driving tasks. Accident Analysis and Prevention, 42(6), 1855-1865. https://doi.org/10.1016/j.aap.2010.05.006

Sabahiah, N., Sukor, A., Tarigan, A. K. M., \& Fujii, S. (2017). Analysis of correlations between psychological factors and self-reported behavior of motorcyclists in Malaysia, depending on self-reported usage of different types of motorcycle facility. Transportation Research Part F: Psychology and Behaviour, 46, 509-523. https://doi.org/10.1016/j.trf.2016.09.032

Sadeghniiat-haghighi, K., Yazdi, Z., \& Mohammad, A. (2016). Sleep quality in long haul truck drivers : A study on Iranian national data. Chinese Journal of Traumatology, 19(4), 225228. https://doi.org/10.1016/j.cjtee.2016.01.014 
Sagaspe, P., Taillard, J., Åkersted, T., Bayon, V., Espié, S., Chaumet, G., ... Philip, P. (2008). Extended driving impairs nocturnal driving performances. PLoS ONE, 3(10). https://doi.org/10.1371/journal.pone.0003493

Sagberg, F. (1999). Road accidents caused by drivers falling asleep. Accident Analysis and Prevention, 31(6), 639-649. https://doi.org/10.1016/S0001-4575(99)00023-8

Smith, S. S., Horswill, M. S., Chambers, B., \& Wetton, M. (2009). Hazard perception in novice and experienced drivers: The effects of sleepiness. Accident Analysis and Prevention, 41(4), 729-733. https://doi.org/10.1016/j.aap.2009.03.016

Sparrow, A. R., Mollicone, D. J., Kan, K., Bartels, R., Satterfield, B. C., Riedy, S. M., ... Dongen, H. P. A. Van. (2016). Naturalistic field study of the restart break in US commercial motor vehicle drivers: Truck driving, sleep, and fatigue. Accident Analysis and Prevention, 93, 55-64. https://doi.org/10.1016/j.aap.2016.04.019

Sullman, M. J. M., Meadows, M. L., \& Pajo, K. B. (2002). Aberrant driving behaviours amongst New Zealand truck drivers. Transportation Research Part F: Traffic Psychology and Behaviour, 5(3), 217-232. https://doi.org/10.1016/S1369-8478(02)00019-0

Tefft, B. C. (2012). Prevalence of motor vehicle crashes involving drowsy drivers, United States, 1999-2008. Accident Analysis and Prevention, 45, 180-186. https://doi.org/10.1016/j.aap.2011.05.028

Teoh, E. R., Carter, D. L., Smith, S., \& McCartt, A. T. (2017). Crash risk factors for interstate large trucks in North Carolina. Journal of Safety Research, 62, 13-21. https://doi.org/10.1016/j.jsr.2017.05.002

Thiffault, P., \& Bergeron, J. (2003). Monotony of road environment and driver fatigue: a simulator study. Accident Analysis and Prevention, 35, 381-391.

Thompson, J., Newnam, S., \& Stevenson, M. (2015). A model for exploring the relationship between payment structures, fatigue, crash risk, and regulatory response in a heavy-vehicle transport system. Transportation Research Part A: Policy and Practice, 82, 204-215. https://doi.org/10.1016/j.tra.2015.09.016

Thompson, J., \& Stevenson, M. (2014). Associations Between Heavy-Vehicle Driver Compensation Methods, Fatigue-Related Driving Behavior, and Sleepiness. Traffic Injury Prevention, 15(sup1), S10-S14. https://doi.org/10.1080/15389588.2014.928702

Ting, P.-H., Hwang, J.-R., Doong, J.-L., \& Jeng, M.-C. (2008). Driver fatigue and highway driving: A simulator study. Physiology \& Behavior, 94(3), 448-453. https://doi.org/10.1016/j.physbeh.2008.02.015

Tsao, L., Chang, J., \& Ma, L. (2017). Fatigue of Chinese railway employees and its influential factors: Structural equation modelling. Applied Ergonomics, 62, 131-141. https://doi.org/10.1016/j.apergo.2017.02.021

Tseng, C., Yeh, M., Tseng, L., Liu, H., \& Lee, M. (2016). A comprehensive analysis of factors leading to speeding offenses among large-truck drivers. Transportation Research Part F: Psychology and Behaviour, 38, 171-181. https://doi.org/10.1016/j.trf.2016.02.007

Tzamalouka, G., Papadakaki, M., \& Chliaoutakis, J. El. (2005). Freight transport and non- 
driving work duties as predictors of falling asleep at the wheel in urban areas of Crete. Journal of Safety Research, 36(1), 75-84. https://doi.org/10.1016/j.jsr.2004.12.003

Urie, Y., Velaga, N. R., \& Maji, A. (2016). Cross-sectional study of road accidents and related law enforcement efficiency for 10 countries: A gap coherence analysis. Traffic Injury Prevention, 17(7), 686-691. https://doi.org/10.1080/15389588.2016.1146823

Watling, C. N., Armstrong, K. A., Obst, P. L., \& Smith, S. S. (2014). Continuing to drive while sleepy: The influence of sleepiness countermeasures, motivation for driving sleepy, and risk perception. Accident Analysis and Prevention, 73, 262-268. https://doi.org/10.1016/j.aap.2014.09.021

Watt, T., Groenvold, M., Bjorner, J. B., Noerholm, V., Rasmussen, N. A., \& Bech, P. (2000). Fatigue in the Danish general population. Influence of sociodemographic factors and disease. Journal of Epidemiology and Community Health, 54(11), 827-833. https://doi.org/10.1136/jech.54.11.827

Williamson, A., \& Friswell, R. (2011). Investigating the relative effects of sleep deprivation and time of day on fatigue and performance. Accident Analysis and Prevention, 43(3), 690-697. https://doi.org/10.1016/j.aap.2010.10.013

Williamson, A., \& Friswell, R. (2013). The effect of external non-driving factors, payment type and waiting and queuing on fatigue in long distance trucking. Accident Analysis and Prevention, 58, 26-34. https://doi.org/10.1016/j.aap.2013.04.017

Williamson, A. M., Feyer, A.-M., \& Friswell, R. (1996). The impact of work practices on fatigue in long distance truck drivers. Accident Analysis \& Prevention, 28(6), 709-719. https://doi.org/10.1016/S0001-4575(96)00044-9

World Health Organization. (2013). Media centre Road traffic injuries. Retrieved from http://www.who.int/mediacentre/factsheets/fs358/en/index.html\#

Zhang, G., Yau, K. K. W., Zhang, X., \& Li, Y. (2016). Traffic accidents involving fatigue driving and their extent of casualties. Accident Analysis and Prevention, 87, 34-42. https://doi.org/10.1016/j.aap.2015.10.033

Zhang, H., Yan, X., Wu, C., \& Qiu, T. Z. (2014). Effect of Circadian Rhythms and Driving Duration on Fatigue Level and Driving Performance of Professional Drivers. Transportation Research Record: Journal of the Transportation Research Board, 2402(1), 19-27. https://doi.org/10.3141/2402-03 
Table A.1 Description of various payment related motivations influencing driving behavior.

\begin{tabular}{|c|c|c|}
\hline Question in the questionnaire & Payment related motivation & $\begin{array}{l}\text { 'Yes' } \\
(\mathbf{N}=453)\end{array}$ \\
\hline $\begin{array}{l}\text { 1. Are you being additionally paid for any non-driving works } \\
\text { such as loading, unloading, waiting in queues etc.? }\end{array}$ & $\begin{array}{l}\text { Additional payment for non- } \\
\text { driving works }\end{array}$ & 50 \\
\hline $\begin{array}{l}\text { 2. Do you receive any financial reward for early or on time } \\
\text { arrivals? }\end{array}$ & Reward for timed deliveries & 54 \\
\hline 3. Do you receive any financial penalty for late arrival? & Penalty for late arrivals & 98 \\
\hline $\begin{array}{l}\text { 4. Do you get involved in non-driving works (like loading- } \\
\text { unloading) when you are paid for it? }\end{array}$ & $\begin{array}{l}\text { Involvement in non-driving } \\
\text { works }\end{array}$ & 53 \\
\hline $\begin{array}{l}\text { 5. Is there any pressure of timed delivery of goods/material } \\
\text { carried by you that affects your job (in turn your salary) or } \\
\text { driving actions? }\end{array}$ & Time pressure & 113 \\
\hline $\begin{array}{l}\text { 6. Do you believe that payment incentives for overtime motivate } \\
\text { you to take lengthy trips i.e. drive more hours or more kms? }\end{array}$ & $\begin{array}{l}\text { Willingness for overtime (or } \\
\text { lengthy trips) }\end{array}$ & 124 \\
\hline $\begin{array}{l}\text { 7. Will you prefer to take night shift }(8 \mathrm{pm}-8 \mathrm{am}) \text { over day shift } \\
\text { for any additional payment? }\end{array}$ & $\begin{array}{l}\text { Willingness to prefer night shift } \\
\text { for extra payment }\end{array}$ & 184 \\
\hline $\begin{array}{l}\text { 8. Does intention of saving fuel (hence saving money) motivate } \\
\text { your driving actions like preferring short uncomfortable routes } \\
\text { in a lengthy trip? }\end{array}$ & $\begin{array}{l}\text { Willingness to take short } \\
\text { uncomfortable routes during a } \\
\text { lengthy trip to save fuel }\end{array}$ & 168 \\
\hline $\begin{array}{l}\text { 9. If incentives are associated with specified timings and } \\
\text { schedules in your driving, then does it motivate you to violate } \\
\text { speeding and other traffic regulations? }\end{array}$ & Willingness to over speed & 105 \\
\hline $\begin{array}{l}\text { 10. If incentives are associated with specified timings and } \\
\text { schedules in your driving, then does it motivate you to drive } \\
\text { more hours continuous or avoid breaks in long trips? }\end{array}$ & $\begin{array}{l}\text { Willingness to avoid rest breaks } \\
\text { in lengthy trips }\end{array}$ & 110 \\
\hline
\end{tabular}

